\title{
Modelling energy transitions for climate targets under landscape and actor inertia
}

\author{
Accepted Manuscript: $14^{\text {th }}$ August 2016, Environmental Innovation and \\ Societal Transitions
}

doi: 10.1016/j.eist.2016.08.002

\author{
Francis G. N. Lia, francis.li@ucl.ac.uk \\ Neil Strachana, n.strachan@ucl.ac.uk \\ a UCL Energy Institute, Central House, 14 Upper Woburn Place, London, WC1H oNN, \\ United Kingdom \\ (c) 2016. This manuscript version is made available under the CC-BY-NC-ND 4.0 \\ license http://creativecommons.org/licenses/by-nc-nd/4.0/
}

\begin{abstract}
The speed at which established socioeconomic and technological systems can be adapted to alternatives that are compatible with a climate stabilised, $2^{\circ} \mathrm{C}$ world remains unknown. Quantitative models used for assessing this challenge typically make a number of arguably optimistic assumptions regarding human behaviour and decision making. This often restricts the insights produced to futures approximating a so-called first-best policy landscape. However, empirical studies of socio-technical change have shown that technological diffusion is often influenced by actors and institutions interacting under less ideal, second-best conditions. This paper quantifies these factors in a formal energy model as landscape and actor inertia and employs them for the first time in BLUE, a dynamic stochastic socio-technical simulation of technology diffusion, energy and emissions inspired by the multi-level perspective. Using the UK energy system as an example, the results illustrate how socio-technical inertia may significantly blunt future efforts to achieve climate targets.
\end{abstract}

\section{Keywords}

Socio-technical change; transitions; energy systems; modelling; decarbonisation; climate policy;

\section{Highlights}

- We present a quantitative socio-technical energy transitions model inspired by the Multi-Level Perspective

- BLUE is a stochastic system dynamic model that features multiple actors with detailed behavioural parameters

- The feasibility of UK climate targets is explored under landscape and actor inertia

- The results show that actor inertia may significantly increase the difficulty of achieving climate targets

- The results also show the importance of taking socio-technical perspectives on energy transitions 


\subsection{Introduction}

\subsection{Modelling energy transitions in "second-best" policy worlds}

The Paris Agreement sets out an international framework for stabilising emissions of greenhouse gases (GHGs), with an aspirational target to hold mean global temperature rise to at least $2^{\circ} \mathrm{C}$ by the end of the century [1]. The Intergovernmental Panel on Climate Change (IPCC) has shown that to have a "likely" (>66\%) chance of achieving this goal, global emissions must fall rapidly by mid-century and be almost negligible by 2100 [2]. While current national pledges fall short of action consistent with this target [3], and the framing of the targets as temperature limits is itself, contested [4], it is agreed that an effective mitigation response will require large-scale changes to established energy systems [5].

The scale of the energy transition challenge is extremely daunting. While there is a diversity of views on which technological, behavioural, lifestyle and political changes might be required in different contexts and at different scales, a common theme runs through almost all of the literature: the urgency required for the transition. While the theoretical possibility of achieving climate targets is generally accepted, the speed at which established socioeconomic and technological systems can be adapted to alternatives that are compatible with a $2^{\circ} \mathrm{C}$ world remains unknown.

Quantitative models used for assessing this unprecedented challenge typically make a large number of arguably optimistic assumptions regarding human behaviour and decision making, as well as future social and political conditions. A majority of longterm decarbonisation studies assume that key actors will make investment decisions in a rational, cost optimal fashion, and that future governments will be able to forge a social consensus that is conducive to taking action in spite of resistance from vested interests. Most studies also assume that a political mandate can be obtained to put in place long-term policies to price externalities and correct the market failures that lead to GHG pollution. Work using these idealised assumptions, sometimes referred to as "first-best" conditions, is often critiqued as overestimating the speed of transitions while simultaneously underestimating their costs [6]. There is therefore a strong interest in exploring climate targets under so-called "second-best" worlds where the "messy policy landscape" found in reality is better acknowledged [7].

It is argued that capturing the behaviour of key energy system actors, and in particular, how their behaviour might co-evolve through time as energy transitions unfold, is key to improving the utility of energy economic models for policy design [8]. A classic taxonomy of energy economic models, developed by Hourcade et al. [9], identifies macro-economics, technological detail, and micro-economic realism as the key dimensions of study required for future advancement of the field. We argue in this paper that improving the representation of decision making and actor dynamics in energy models requires not only a better depiction of investment choices in the micro-economic sense, but also a broader set of structural changes aimed at improving overall societal realism. To inform this perspective we draw on the substantial insights provided by the interdisciplinary field of socio-technical transitions [10]. 


\subsection{The multi-level perspective (MLP) on socio-technical transitions}

The behaviour of key institutions or actors has been observed as a major factor influencing past technological transitions, suggesting that technologies are firmly embedded within particular social and political contexts [11]. The literature on sociotechnical transitions advocates the concept of studying not only technologies, but their role in society as part of integrated "socio-technical systems". This expands the common, engineering-derived definition of "system" to include not only networks of technological artefacts but also the associated supporting institutions and individuals who use them $[12,13]$. Benjamin Sovacool sums up the co-evolving nature of sociotechnical change by observing that "To be successful, technologies must not only get built, but get built into society" [14].

As noted above, a rapid energy transition towards a $2^{\circ} \mathrm{C}$ world by the mid $-21^{\text {st }}$ century implies a radical restructuring of the established order, which is dominated by fossil fuel technologies, infrastructures and institutions. Together, these form what is often referred to in the literature as a powerful "socio-technical regime", effectively a reigning champion that is difficult for new challengers to displace. A strong incumbent regime not only dominates the playing field but also to some extent affects the rules of the game by which others must play. It's very existence creates path dependencies and socio-technical "lock-in" to an environmentally harmful paradigm $[15,16]$. Studying the conditions which enable systems to break out from locked-in states is a key activity in the transitions research community [17].

One of the most widely used frameworks for exploring socio-technical change is the multi-level perspective (MLP) of Geels [18] (see Figure 1). Essentially, under the MLP framework, innovative "niche" technologies have their performance and costs improved over time under the support of powerful actors [19]. Shifts in macro-scale "landscape" conditions, such as government intervention in markets or changes in social preferences $[20,21]$ may then create periodic windows of opportunity for these innovations to disrupt the status quo and enter the mainstream. In this paper, we aim to replicate these dynamics in a quantitative model for the purposes of analysing the viability of achieving climate targets in a national energy system. We note that quantitative model outputs still require qualitative interpretation, and we see this formal modelling activity as one that must be developed in parallel with qualitative studies of transitions (we elaborate further in discussion under Section 5.2). 
Figure 1-Socio-technical change, represented under the multi-level perspective (MLP) on sustainability transitions (based on [18])

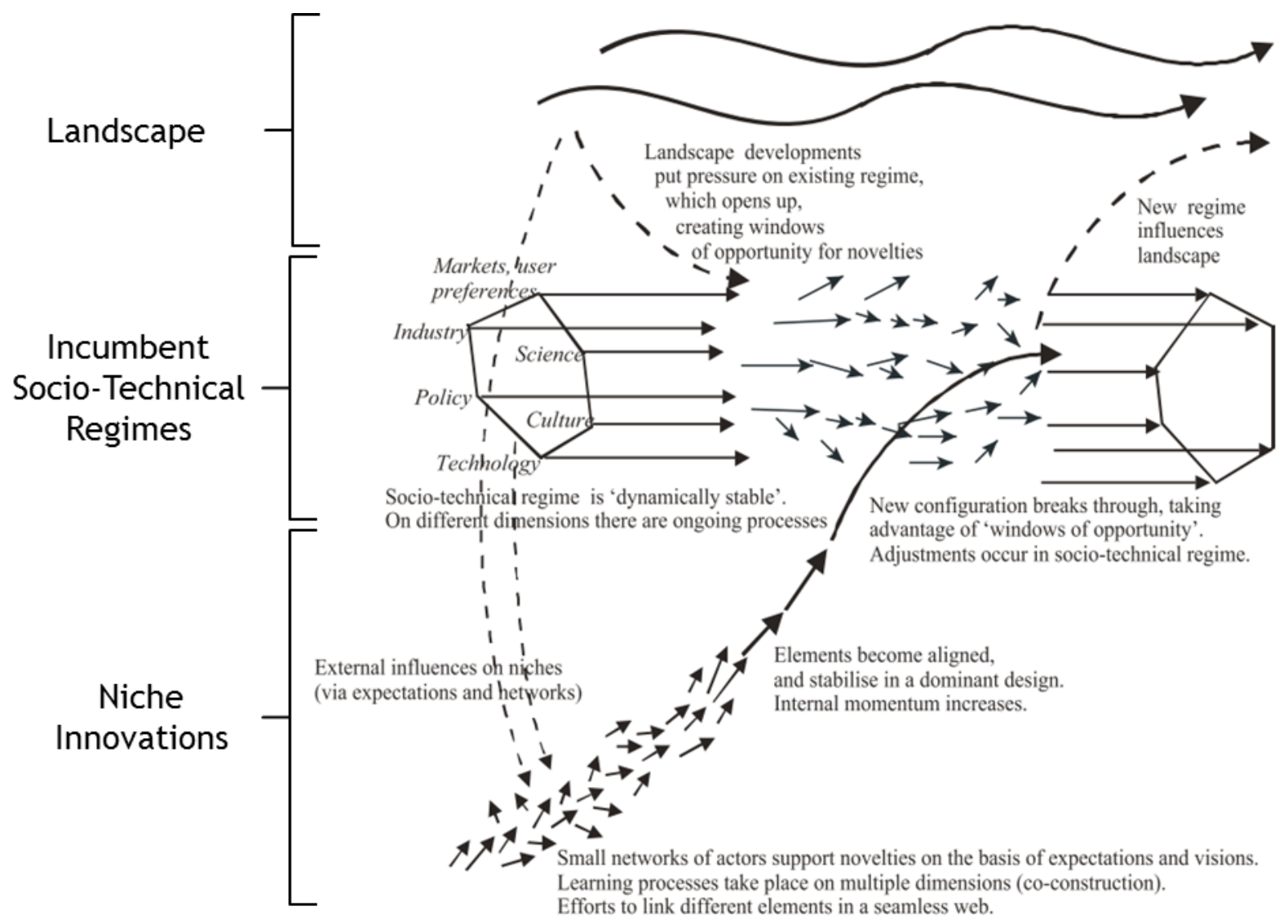

\subsection{Actor and landscape inertia}

The historical diffusion of innovative energy technologies into mainstream use has generally been slow, occurring along decadal timescales rather than in the space of a few years. An extensive review by IIASA researchers found that energy technologies have historically taken between $80-130$ years to achieve market dominance from their initial commercialization [22]. To limit anthropogenic warming along the timescales required by the Paris Agreement, transitions to new energy technologies may need to occur at rates that could be considered extremely rapid by historical standards.

Researchers have speculated about the social and political conditions that could be required to bring about such a rapid shift. Some have invoked the idea of conditions approximating a "war economy" or the Apollo space program to bring about a completely transformed energy system in $40-50$ years $[23,24]$, while sceptics have noted that these herculean efforts have historically been difficult to sustain over long periods, typically burning out after less than a decade [25]. Running a war economy requires political and social consensus, which is currently absent from the energy transition landscape. Currently, we observe that the dominance of the incumbent fossil-fuelled regime is facilitated by macro-scale social and political conditions (referred to in the MLP tradition as the "landscape"), which maintain carbon pollution 
from fossil fuel use as an unresolved externality. In this paper, we refer to the formidable barrier to systemic change posed by current socio-political conditions as "landscape inertia".

While landscapes in transitions studies are often cast as sets of contextual factors that can change only at a glacial pace [26], there has been some support for the idea of exploring their implementation as a dynamic element [18]. van (Hugo) Driel and Schot [27], for example, propose the disaggregation of landscapes using a taxonomy that distinguishes between largely immutable factors (such as physical climate), longterm trend patterns (such as demographics or economic structure), and rapid external shocks (such as oil price fluctuations). Our exploration of landscape inertia in this study operationalises the concept in a more dynamic fashion than is typical in many qualitative studies of socio-technical change. However, dynamic representations of the landscape are common in exploratory transitions modelling (e.g. [28] or [29]).

As well as landscape inertia, we also explore an inertial effect that occurs at the level of individual decision makers. When individuals act as consumers allocating their personal time and capital, they make heterogeneous choices. Costs form a strong component of decision making, but individual decisions may also be affected by habits, the influence of family, friends and neighbours, and wider social norms [30]. Individuals often make economic choices that are sub-optimal, in the sense of neoclassical economics, acting in the absence of perfect information and under conditions of bounded rationality [31]. Whether or not these individual preferences can be aggregated across large populations and adequately explained by a rational choice model of decision making, or whether more complex models may be required to explore behaviour, remains an ongoing field of discussion within economic theory [32]. However, there are a number of well-documented areas where rational choice behaviour does not appear to play out in energy policy. For example, in many countries there has been a widespread failure (often termed "the energy efficiency gap" [33]) to incentivise market players and individual householders to invest in building energy efficiency measures, a supposed "low hanging fruit" with few noncost barriers [34,35]. This effect is an example of what we will explore in this paper as "actor inertia".

\subsection{Quantitative modelling of socio-technical transitions in energy}

While technological transitions frameworks like the MLP elegantly describe transition dynamics, such as regime resistance to change, a general critique is often raised that they can be difficult to operationalize for the purposes of informing policy $[36,37]$. Formal quantitative models of energy systems, on the other hand, are recognised as an important part of an iterative evidence-based policy process [38], but often employ highly simplified representations of actor dynamics and choice behaviour. Several detailed review papers provide an understanding of the typical model types that are used in energy futures research [39-41]. A common approach is to assume that individual consumers will make cost-optimal choices when presented with a range of technological options and that this will hold true for the whole population when taken in aggregate [42]. However, as discussed previously, this potentially 
overlooks insights from other disciplines with a rich tradition of developing models of decision making, such as behavioural economics, psychology and sociology [30].

Modelling carried out for the IPCC Fifth Assessment Report acknowledges that "changes in institutional structures will be required to facilitate the technological change envisaged in the scenarios" and that "non-optimal or real world institutional conditions can influence how technological pathways evolve" [43]. There is widespread recognition that a focus on technologies alone faces limits to delivering public policy solutions to environmental challenges, that interdisciplinary theories of technological change are urgently needed [44], and that research should seek to integrate behavioural and social insights into quantitative energy modelling $[45,46]$.

One response has been a push in the research community towards developing and using formal models of innovation and technological change inspired by sociotechnical transitions theories such as the MLP (e.g. [29]). A detailed review by Li, Trutnevyte and Strachan [47] identified existing socio-technical energy transition (STET) models in the energy supply, buildings and transport sectors and proposed a taxonomy for describing their key characteristics, as illustrated in Figure 2. 
Figure 2-Taxonomy of socio-technical energy transition (STET) models (based on [47])

$\begin{array}{ll}\text { (A) Techno-Economic Detail } & \text { (B) Explicit Actor Heterogeneity }\end{array}$

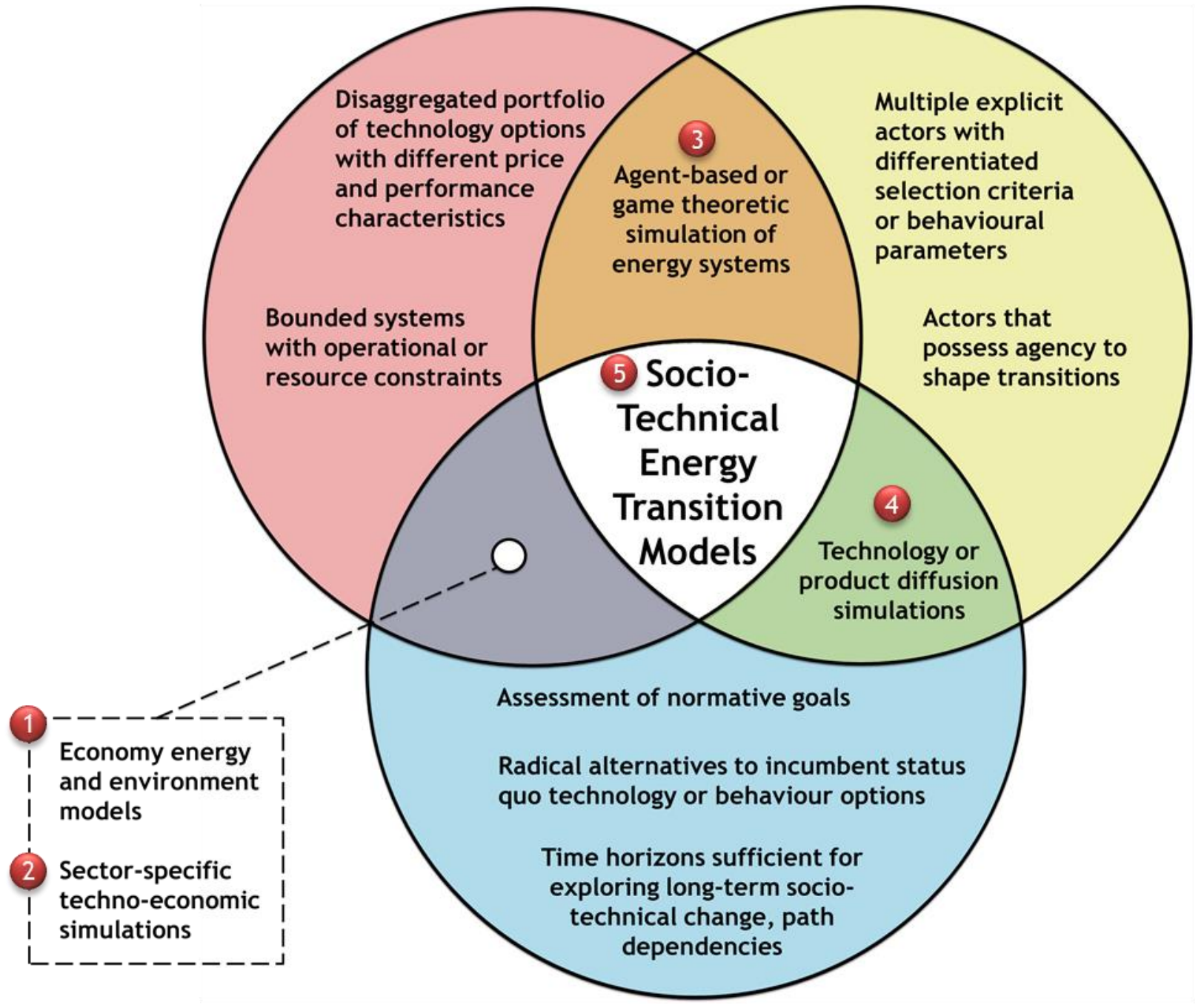

(C) Transition Pathway Dynamics

Li et al. argue that while a small number of models exist that combine the key elements $A-C$, the most frequently encountered model families (labelled $1-4$ in Figure 2) are generally not appropriate for explicit modelling of socio-technical change without extensive modification. The strengths and weaknesses of different model types for modelling socio-technical transitions are summarised below in Table 1. 
Table 1-Strengths and weaknesses of different model types for transitions research

\begin{tabular}{|c|c|c|c|c|}
\hline \# & Model Type & $\begin{array}{l}\text { Energy Research } \\
\text { Examples }\end{array}$ & $\begin{array}{l}\text { Strengths for Modelling of Socio- } \\
\text { technical Transitions }\end{array}$ & $\begin{array}{l}\text { Weaknesses for Modelling of Socio- } \\
\text { technical Transitions }\end{array}$ \\
\hline 1 & $\begin{array}{l}\text { Economy energy } \\
\text { and environment } \\
\text { models }\end{array}$ & $\begin{array}{l}\text { National and global } \\
\text { scale energy system } \\
\text { optimisation models } \\
\text { (ESOMs) }[48,49] \\
\text { Global scale integrated } \\
\text { assessment models } \\
\text { (IAMs) [50] }\end{array}$ & $\begin{array}{l}\text { Granular technological detail } \\
\text { enables exploration of technological } \\
\text { substitution dynamics in transitions. } \\
\text { Multi-sectoral economic } \\
\text { optimisation approach allows } \\
\text { complex trade-offs between } \\
\text { different options and across } \\
\text { different sectors to be explored for } \\
\text { transitions. }\end{array}$ & $\begin{array}{l}\text { Technological detail usually lower than } \\
\text { in comparable sector-specific models. } \\
\text { Complex dynamics amongst multiple } \\
\text { transition actors subsumed into single } \\
\text { social planning agent who acts with } \\
\text { unlimited agency and perfect foresight. } \\
\text { Economic choice behaviour of social } \\
\text { planner usually abstracted to } \\
\text { neoclassical optimality. }\end{array}$ \\
\hline 2 & $\begin{array}{l}\text { Sector-specific } \\
\text { techno-economic } \\
\text { simulations }\end{array}$ & $\begin{array}{l}\text { Buildings [51] } \\
\text { Heat [52] } \\
\text { Electricity [53] } \\
\text { Transport [54] }\end{array}$ & $\begin{array}{l}\text { High levels of technological detail for } \\
\text { exploring transitions, often going } \\
\text { beyond broad technology categories } \\
\text { to represent specific sizes or } \\
\text { engineering design variants of } \\
\text { systems. } \\
\text { Simulation approach often lends } \\
\text { itself well to spatially detailed } \\
\text { studies that may even incorporate } \\
\text { GIS analysis (e.g. [55]) to relate } \\
\text { transition impacts to real world } \\
\text { locations. }\end{array}$ & $\begin{array}{l}\text { Socio-technical transitions that cut } \\
\text { across multiple sectors (such as the } \\
\text { decarbonisation of electricity supply) } \\
\text { are difficult to analyse i.e. the depth in } \\
\text { single-sector models often comes at the } \\
\text { expense of breadth. } \\
\text { Human behaviour and economic } \\
\text { elements of socio-technical transitions } \\
\text { are often left outside of the scope of } \\
\text { analysis. }\end{array}$ \\
\hline 3 & $\begin{array}{l}\text { Agent-based } \\
\text { models of energy } \\
\text { systems }\end{array}$ & $\begin{array}{l}\text { Electricity }[56] \\
\text { Transport }[57,58]\end{array}$ & $\begin{array}{l}\text { Agent-based approach captures } \\
\text { interactions of multiple actors as } \\
\text { transitions unfold, often with } \\
\text { detailed consideration given to } \\
\text { behavioural parameters such as } \\
\text { economic choice. }\end{array}$ & $\begin{array}{l}\text { Models frequently focus on capturing } \\
\text { the complex dynamics of the present } \\
\text { day system but often fail to capture how } \\
\text { these relationships may transition } \\
\text { through time in response to the } \\
\text { emergence of radical technologies, } \\
\text { changes to landscape conditions like } \\
\text { regulatory and market frameworks or } \\
\text { long term shifts in fuel prices and } \\
\text { behavioural preferences. }\end{array}$ \\
\hline 4 & $\begin{array}{l}\text { Technology or } \\
\text { product diffusion } \\
\text { simulations }\end{array}$ & $\begin{array}{l}\text { Bioenergy in the } \\
\text { power sector [59] } \\
\text { Hydrogen in the road } \\
\text { transport sector [6o] }\end{array}$ & $\begin{array}{l}\text { Models use agent-based or dynamic } \\
\text { simulation approaches to capture } \\
\text { both inter-actor dynamics and also } \\
\text { changes to the selection } \\
\text { environment as transitions unfold } \\
\text { (e.g. technology performance, } \\
\text { prices, behavioural preferences). }\end{array}$ & $\begin{array}{l}\text { Models tend to be designed to focus on } \\
\text { a single niche technology or product of } \\
\text { interest, so lack the capability to } \\
\text { represent trade-offs between a broad } \\
\text { portfolio of alternatives. } \\
\text { Models tend to simulate uptake or } \\
\text { growth of a technology within a target } \\
\text { market segment, typically limiting the } \\
\text { analysis to a single sector and making it } \\
\text { difficult to explore complex multi- } \\
\text { sectoral transitions. }\end{array}$ \\
\hline
\end{tabular}




\begin{tabular}{|l|l|l|l|l|}
\hline 5 & $\begin{array}{l}\text { Socio-technical } \\
\text { energy transition } \\
\text { (STET) Models }\end{array}$ & $\begin{array}{l}\text { Power [61] } \\
\text { Energy demand } \\
\text { and supply [62] } \\
\text { Transport [28] } \\
\text { Buildings [63] }\end{array}$ & $\begin{array}{l}\text { Models successfully combine } \\
\text { techno-economic detail, behavioural } \\
\text { heterogeneity and transition } \\
\text { pathway dynamics to capture } \\
\text { elements of socio-technical change } \\
\text { in a formal analytical framework }\end{array}$ & $\begin{array}{l}\text { Models complex to validate } \\
\text { Such a highly inter-disciplinary } \\
\text { approach may never deliver the types of } \\
\text { detailed insights in any single domain } \\
\text { (behaviour, technology, transition } \\
\text { dynamics) that more tightly focused } \\
\text { models may be able to provide, and } \\
\text { may struggle to capture the widest } \\
\text { economic and environment interactions }\end{array}$ \\
\hline
\end{tabular}

\subsection{Summary of aims and objectives}

In any socio-technical transition, the rate of change is affected by the social and political contexts into which new technologies are deployed. To date, a majority of model-based analyses that are aimed at quantifying transition pathways to a climate stabilised future have employed only a limited depiction of actor behaviour, and focused mainly on "first-best" conditions that potentially underplay the challenges posed by social and political barriers. In this paper, we conceptualise the resistance to change arising from incumbent institutional arrangements, established behaviours and lifestyles as "landscape and actor inertia". We present here a socio-technical energy transition (STET) model of the UK energy system, the Behaviour Lifestyles and Uncertainty Energy model (BLUE). BLUE is conceptually aligned with one of the most frequently employed heuristic frameworks for exploring socio-technical change, the multi-level perspective (MLP) [18].

A wide ranging review of existing STET models [47] found examples applied to the energy demand and supply, power, buildings and transport sectors, but none which assessed the feasibility of achieving climate targets across a whole national energy system. In this paper we take the UK as an example of a country that has a binding long term energy systems decarbonisation target. We use BLUE to explore the effect that different levels of landscape and actor inertia have on the rate of technological change in the energy system and its' ability to meet climate targets. The work illustrates the magnitude of the challenges posed by systemic inertia, and contributes to the new interdisciplinary research frontier of socio-technical energy transition modelling. The remainder of the paper is structured as follows:

- Section 2.0 introduces the BLUE model and details some of its key features, as well as describing how it is currently calibrated for UK policy analysis.

- Section 3.o details the scenario dimensions used to explore landscape and actor inertia.

- Section 4.0 presents the results, which show the effect of landscape and actor inertia on the UK energy system's ability to meet climate targets.

- Section 5.0 discusses the implications for policy and for research, suggesting possible avenues for future investigation.

- Section 6.o concludes by summarising the key findings and recommendations of the paper. 


\subsection{BLUE model overview}

\section{$2.1 \quad$ Topology and concept}

The Behaviour, Lifestyles and Uncertainty Energy model (BLUE), is a system dynamic model of the UK energy system that simulates energy use and emissions through time as an energy transition unfolds. BLUE is implemented in the Analytica modelling environment developed by Lumina Decision Systems. BLUE is conceptually aligned with the multi-level perspective (discussed in Section 1.2) in that it has landscape, regime and niche levels, as illustrated in Figure 3. Rather than relying on a single omnipotent social planner to allocate resources, BLUE is configured with multiple actors, each representing a social planner that is independently responsible for a single economic sector.

BLUE is configured with the following actors: energy supply $(A)$, residential (B), commercial (C), industrial (D), and the various transport sectors (E-H). Together they represent the incumbent socio-technical regime surrounding energy supply. The landscape module contains macro-scale energy system drivers such as economic growth, environmental policy measures, and a range of possible changes to technology costs and fuel prices through time. The niche innovations are represented by a number of key transition technologies $(\mathbf{X})$ and changes to lifestyle ( $Y$ ), which have the potential to disrupt the incumbent socio-technical regime. Calibration checks for total emissions, total primary energy, and electricity demand are used to ensure that the model structure and data in the base year produce results that are within a few percent of government statistics. Further details on the data used to calibrate the model are elaborated in Section 2.3.

Figure 3-BLUE model topology

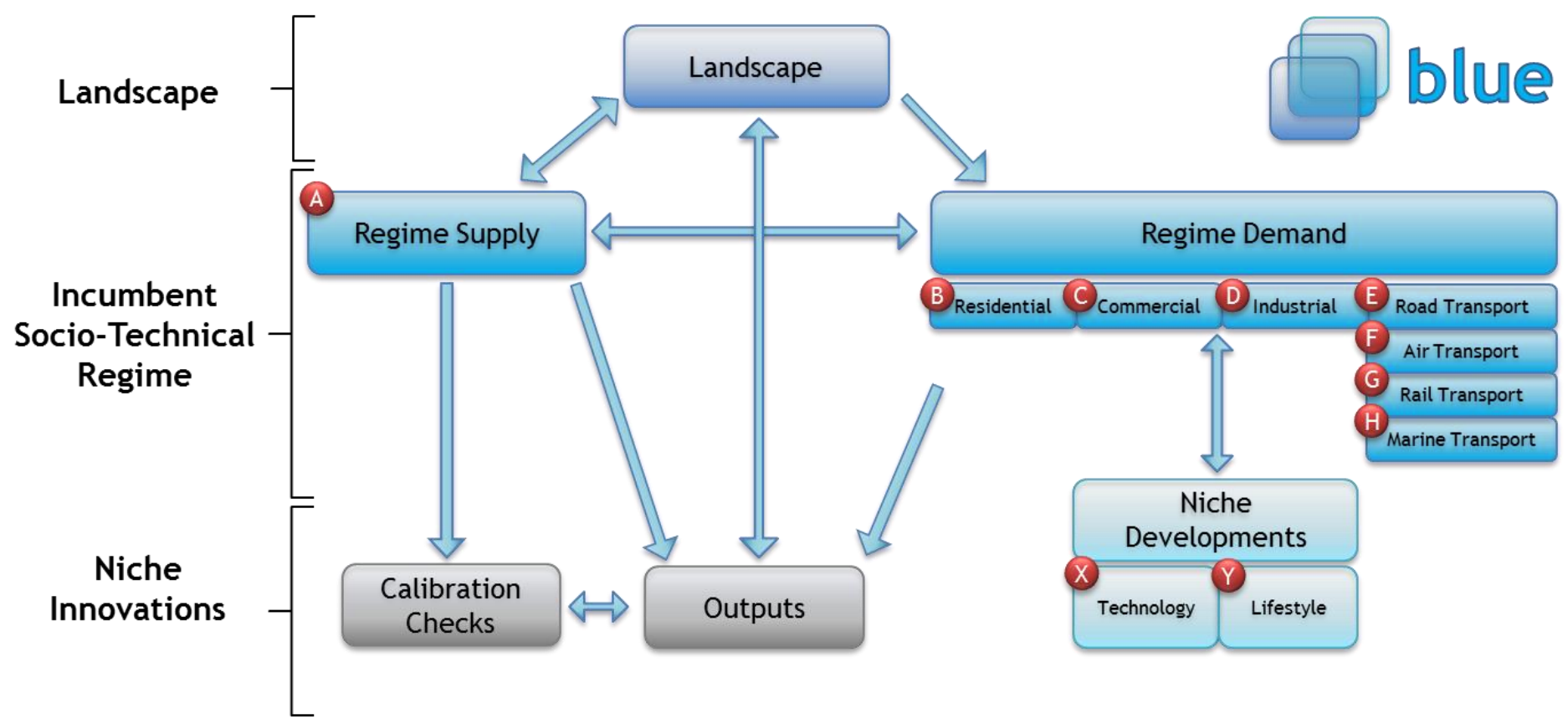

Figure 4 provides a conceptual illustration of how the model operates. BLUE is run in annual time steps over a 40 year time horizon from a 2010 base year out to 2050 . In 
each time step, the individual energy system actors $(\mathbf{A}-\mathrm{H})$ track the condition of the capital stock in their respective sectors. For example, the energy sector actor monitors the age of power stations and other generating plant, and the road transport sector actor monitors the vintages of the vehicles in the transport fleet. As capital assets in each sector reach the end of their economic life and are retired, the system actors have to make decisions about capital stock replacement. In each window of capital stock replacement, each actor attempts to minimize the cost of investments in their respective sectors.

Such actor driven decisions are iteratively made as new niche technologies or lifestyle changes occur, or as landscape pressures - such as fuel price changes or an overall carbon price signal - are implemented (see Sections 3.1, 3.2). A key feature of BLUE is that each actor takes investment decisions with myopic foresight (they have no advance knowledge of future landscape conditions) and with no prior knowledge of how the other key players will react to them. As a result, rather than producing a blueprint for a least-cost transition, as a pathway optimization model would do, BLUE instead captures the dynamic interactions of the different actors through time. Finally, BLUE represents input parameters via discrete or continuous probability distributions (see Section 2.3), hence allowing detailed exploration of the combined uncertainty ranges under which decisions are made, sampled probabilistically via a Monte Carlo approach.

Figure 4-Conceptual socio-technical transition through time in BLUE

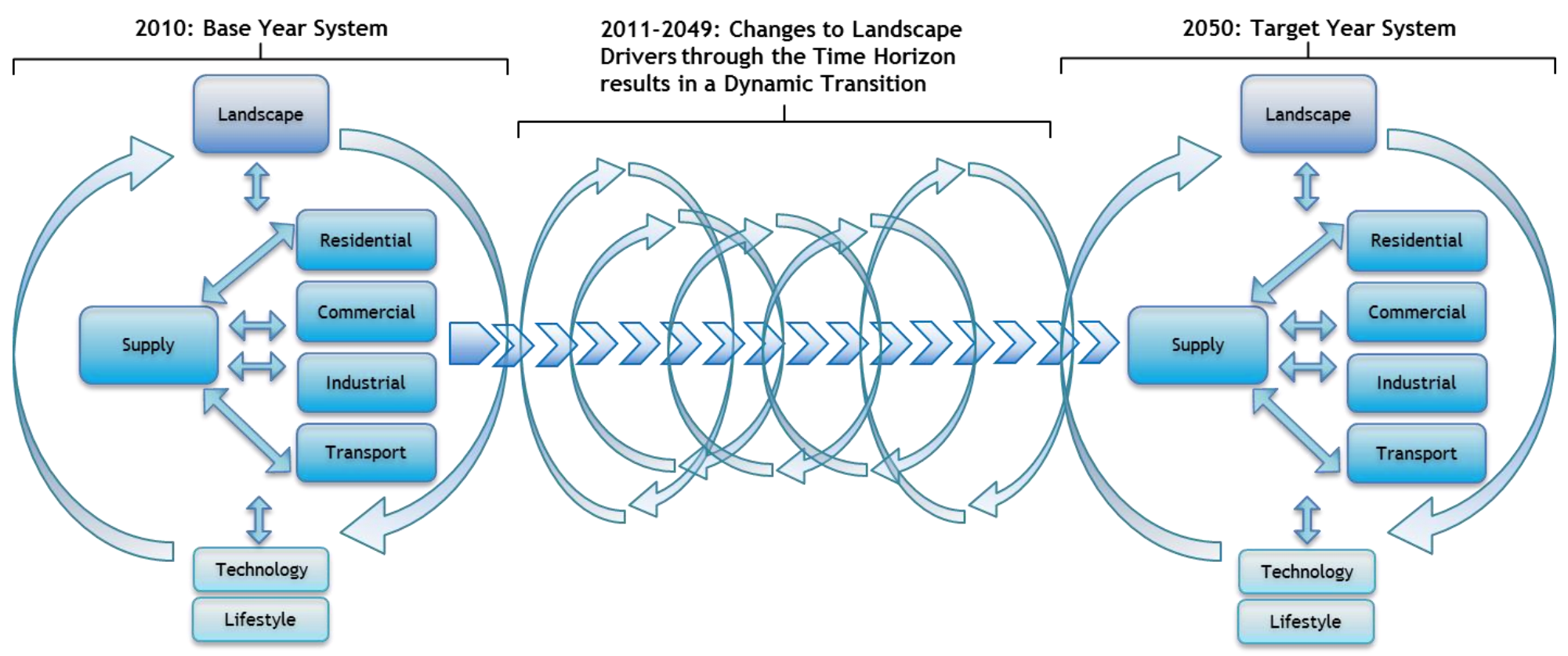


Technology diffusion, total energy use, $\mathrm{CO}_{2}$ emissions and total energy costs are tracked both for individual sectors and across the full energy system for the whole time horizon, enabling the model to be used for assessing normative targets. BLUE operates as a stochastic Monte Carlo simulation, thus capturing a range of input uncertainties in the outputs. This applies not only to key landscape inputs like fuel prices, but also to a number of behavioural parameters (described below), such that uncertainty in the decision making behaviour of the actors can also be characterised.

\subsubsection{Actor behavioural parameters}

BLUE includes a range of parameters that allows the investment behaviour of the different decision makers in the energy system to be differentiated from one another, summarised in Table 2.

Table 2 - Actor behaviour parameters in BLUE

\begin{tabular}{|c|c|c|}
\hline Parameter & Symbol & Description \\
\hline $\begin{array}{l}\text { Demand } \\
\text { elasticities }\end{array}$ & e & $\begin{array}{l}\text { Actors exhibit different levels of sensitivity to changes in energy prices. For example, } \\
\text { some are price-insensitive and continue to use the same amount of energy in the face of } \\
\text { price increases, while others may react to curtail their consumption. }\end{array}$ \\
\hline $\begin{array}{l}\text { Market } \\
\text { heterogeneity }\end{array}$ & $\boldsymbol{v}$ & $\begin{array}{l}\text { Actors have varying sensitivities to cost differentials when making decisions } \\
\text { around investments in new capital assets. For example, some may exhibit } \\
\text { strongly "cost optimising" behaviour, while others may not choose the cheapest } \\
\text { option every time. Individuals make investment choices without the benefit of } \\
\text { perfect information of all their options [64], and different consumers and } \\
\text { companies have different requirements and preferences that blurs the notion of } \\
\text { the "average technology cost". The approach in BLUE to market heterogeneity is } \\
\text { modelled after the approach taken in the CIMS [65] and Res-IRF/IMACLIM-R [63] } \\
\text { hybrid energy economy models. }\end{array}$ \\
\hline $\begin{array}{l}\text { Intangible } \\
\text { costs / } \\
\text { benefits }\end{array}$ & $i$ & $\begin{array}{l}\text { Different actors experience non-monetary costs/benefits from different investment } \\
\text { choices that can be estimated as a parameter in order to include them in the cost-based } \\
\text { choice decision framework. }\end{array}$ \\
\hline Hurdle rates & $r$ & $\begin{array}{l}\text { Actors have different attitudes to investment risk and exhibit varying sensitivities to up- } \\
\text { front economic costs. }\end{array}$ \\
\hline $\begin{array}{l}\text { Retrofitting / } \\
\text { replacement } \\
\quad \text { rate }\end{array}$ & $b$ & Actors have different investment cycles for new capital assets over time. \\
\hline
\end{tabular}




\subsubsection{Energy service demands and energy prices}

Key inputs to BLUE at the landscape level are energy service demands and energy prices. Energy service demands are assumed to grow in line with user-defined drivers that reflect national circumstances. (e.g. residential sector energy demand growth will be a function of elements such as population growth and housing stock levels), and respond not only to demand elasticities but also to the rate of change in energy prices between the current time period and the previous time period. This can be expressed as:

$D_{s, t}=D_{s, t-1} \times\left[1+G_{s}\right] \times\left[e_{s, t-1}\left(1-\Delta P_{s, t-1}\right)\right]$

Where $\boldsymbol{D}=$ energy service demand, $\boldsymbol{s}=$ sector, $\boldsymbol{t}=$ time period, $\boldsymbol{G}=$ demand driver, $\boldsymbol{P}=$ energy price, and $\boldsymbol{e}=$ price elasticity of demand.

Energy prices grow by a user input rate through time, which can be aligned with policy projections or randomised as desired by the user. Energy prices contain a fuel price component and a carbon price component.

$E_{f, t}=\left[P_{f, t-1} \times\left(1+k_{f}\right)\right]+\left[z_{f, t} \times\left\{C O_{2, t-1} \times(1+j)\right\}\right]$

Where $\boldsymbol{E}=$ energy price, $\boldsymbol{P}=$ fuel price, $\boldsymbol{t}=$ time period, $f=$ fuel type, $\boldsymbol{k}=$ periodic fuel price increase/decrease, $\mathrm{CO}_{2}=$ carbon price, $j=$ periodic carbon price increase/decrease and $\boldsymbol{z}=$ specific emissions intensity.

\subsubsection{Capital stock replacement}

In each sector, the model evaluates the net present value of competing technology options. The net present value of available technologies is evaluated by each actor as follows:

$N_{s, t, x}=C_{s, t, x}+i_{s, t, x}+\sum_{t}^{T}\left[\frac{D_{s, t} \times P_{f, t} \times Y_{s, t, x}^{-1}}{\left(1+r_{s, t}\right)^{t}}\right]$

Where $\boldsymbol{N}=$ net present value, $\boldsymbol{s}=$ sector, $\boldsymbol{t}=$ time period, $\boldsymbol{x}=$ energy technology, $\boldsymbol{C}=$ capital investment cost, $i=$ intangible cost, $D=$ energy service demand, $f=$ fuel type, $Y$ $=$ efficiency, $\boldsymbol{r}=$ hurdle rate, $\boldsymbol{T}=$ investment time horizon

\subsubsection{Technology diffusion}

Having determined the net present value, the model then uses it as an input into evaluating technology diffusion into the marketplace.

$M_{s, t, x}=\left[M_{s, t-1, x} \times\left(1-b_{s, t}\right)\right]+\left[M_{s, t-1} \times b_{s, t} \times\left(\frac{N_{s, t}^{-v_{s, t}}}{\sum_{x} N_{s, t}^{-v_{s, t}}}\right)\right]$

Where $\boldsymbol{M}=$ technology portfolio, $\boldsymbol{s}=$ sector $\boldsymbol{t}=$ time period, $\boldsymbol{x}=$ energy technology, $\boldsymbol{b}$ = retrofitting/replacement rate, $\boldsymbol{N}=$ net present value, $\boldsymbol{v}=$ heterogeneity parameter 


\subsubsection{Heterogeneity in BLUE}

The heterogeneity parameter, $\boldsymbol{v}$, and its' effect on technology choice merits some more detailed discussion. Figure 5 illustrates how using different values for the heterogeneity parameter affects technological diffusion when there are two competing technologies (there may of course, be more than two technologies, but the results are simplest to visualise in two dimensions).

In Figure 5 , the relative costs between the incumbent technology and the alternative technology are on the horizontal axis, while the vertical axis represents the fraction of the alternative technology adopted. It can be seen that with a heterogeneity factor of zero, costs effectively play no part in investment decisions, while with high values of $v$ (e.g. $\geq 20$ ), selection behaviour in the model approaches near perfect cost optimality (the lowest cost option is selected almost every time).

Figure 5 -Technological diffusion for different values of the heterogeneity parameter, $\mathrm{v}$

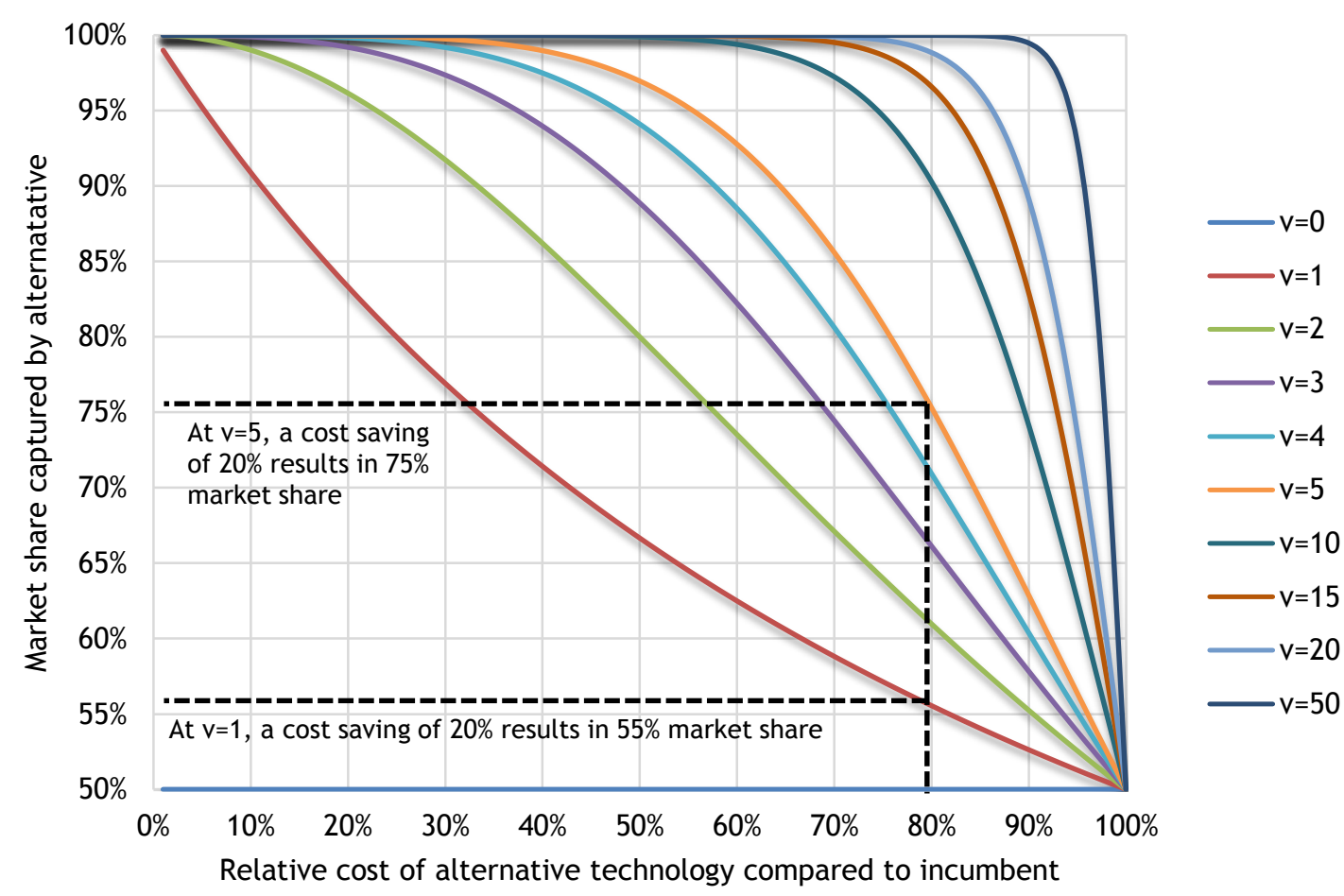


For the purposes of exploring heterogeneity in BLUE, we define a number of descriptive ranges for the heterogeneity parameter, summarised in Table 3.

Table 3-Descriptive definitions for the heterogeneity parameter

\begin{tabular}{|c|c|l|}
\hline Definition & $\boldsymbol{v}$ & \multicolumn{1}{c|}{ Description } \\
\hline $\begin{array}{c}\text { Cost optimising } \\
\text { behaviour }\end{array}$ & $20-50$ & $\begin{array}{l}\text { Actors will choose the least cost option almost every time, even if the savings are very } \\
\text { small. For example, at } \mathbf{v}=50, \text { a } 5 \% \text { saving results in a } 95 \% \text { uptake. }\end{array}$ \\
\hline $\begin{array}{c}\text { Strong price } \\
\text { sensitivity }\end{array}$ & $10-19$ & $\begin{array}{l}\text { In this range, actors react strongly to prices, but prices do not guide all their decisions. } \\
\text { For example, at } \boldsymbol{v}=15, \text { a }>30 \% \text { saving would be needed to drive replacement of the entire } \\
\text { capital stock with the lowest cost alternative. }\end{array}$ \\
\hline $\begin{array}{c}\text { Partial price } \\
\text { sensitivity }\end{array}$ & $5-9$ & $\begin{array}{l}\text { At this setting, actors are price conscious but often very large cost savings are required } \\
\text { before a total switch to new technologies occurs. For example at } \boldsymbol{v}=5, \text { a }>70 \% \text { saving is } \\
\text { required for complete replacement. }\end{array}$ \\
\hline Price insensitive & $0-4$ & $\begin{array}{l}\text { With these inputs, actors do not react strongly to prices. Even large cost savings might } \\
\text { not cause a complete shift to the new technology. }\end{array}$ \\
\hline
\end{tabular}

\subsection{Calibration and key assumptions}

BLUE is calibrated to a 2010 base year for the United Kingdom. Analysis of UK climate targets requires taking a whole systems perspective across all energy using sectors, including supply, buildings, industry, and transport. As noted earlier, the application of BLUE to the UK energy system represents the first time a STET-type model has been used in this fashion, with past works focusing mainly on individual economic sub-sectors. Table 4 gives a set of key model inputs used for calibrating the base demand and cost data, while Table 5 shows the main driving assumptions behind changes to costs and demand levels across the time horizon. To reflect current UK policy thinking, key assumptions about demand growth and fuel prices have been selected to reflect the UK government perspective. Additional model detail and calibration data can be found in the online documentation (see [66]).

Multiple policy analyses show that an energy transition towards a more electrified future using low carbon electricity is an attractive decarbonisation pathway for the UK [67-70]. In this paper we therefore consider various low carbon generation options in the power sector, electric heat pumps for supplying building heating, and electric drivetrain vehicles for road transport. To represent future improvements in these technologies, their costs are assumed to fall over time (although at uncertain rates), effectively capturing different levels of exogenous technological change. Most variables are considered in a probabilistic fashion, using distributions as inputs. For example, Figure 6 illustrates the variation in estimates of electricity generation costs in the model baseline year. 
Figure 6 - Starting year levelised electricity costs (based on [71])

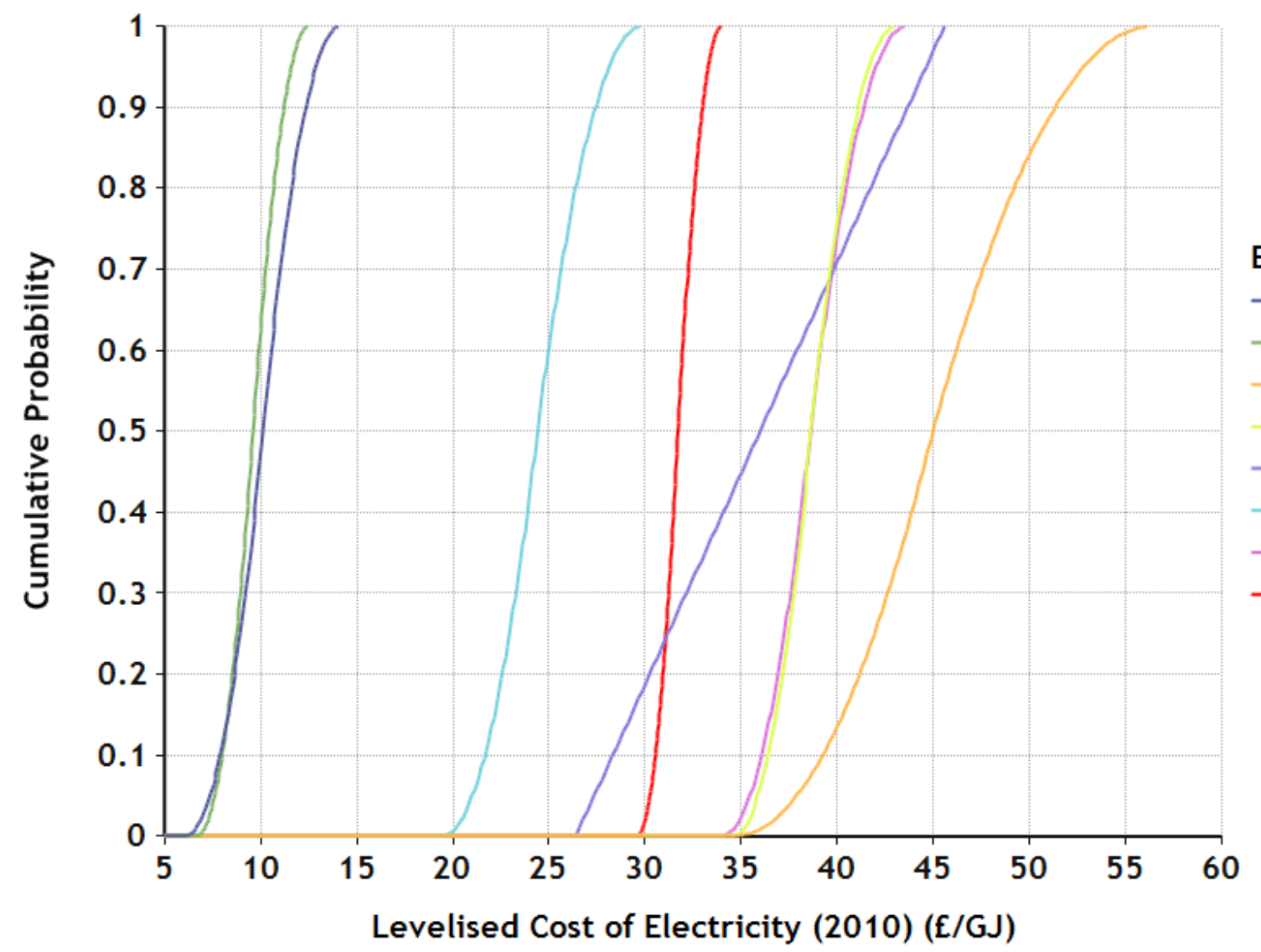

Electricity Technologies

- Coal

- Gas

- Coal-CCS

- Gas-CCS

- Nuclear

- Onshore Wind

- Offshore Wind

- Large Scale PV

Table 4-BLUE base year calibration data for the United Kingdom

\begin{tabular}{|c|c|c|c|c|}
\hline Parameter & Sub-Parameter & $\begin{array}{c}\text { Value } \\
\text { (L=Low, } C=\text { Central, } \mathrm{H}=\text { High) }\end{array}$ & Units & Notes \\
\hline $\begin{array}{l}\text { Energy } \\
\text { Service } \\
\text { Demands }\end{array}$ & $\begin{array}{c}\text { Residential } \\
\text { Commercial } \\
\text { Industrial } \\
\text { Transport (Road) } \\
\text { Transport (Air) } \\
\text { Transport (Rail) } \\
\text { Transport (Marine) }\end{array}$ & $\begin{array}{c}2064 \\
821 \\
1093 \\
1691 \\
515 \\
42 \\
38\end{array}$ & PJ & $\begin{array}{l}\text { UK Department of Energy and } \\
\text { Climate Change (DECC) [72]. }\end{array}$ \\
\hline $\begin{array}{l}\text { Fossil Fuel } \\
\text { Prices }\end{array}$ & $\begin{array}{c}\text { Oil } \\
\text { Coal } \\
\text { Gas }\end{array}$ & $\begin{array}{c}9.69 \\
2.5 \\
4.06\end{array}$ & $f / G J$ & $\begin{array}{l}\text { UK Department of Energy and } \\
\text { Climate Change (DECC) [73]. }\end{array}$ \\
\hline $\begin{array}{l}\text { Power } \\
\text { Generation } \\
\text { Technology } \\
\text { Portfolio }\end{array}$ & $\begin{array}{c}\text { Gas } \\
\text { Coal } \\
\text { Coal-CCS } \\
\text { Gas-CCS } \\
\text { Nuclear }\end{array}$ & $\begin{array}{c}35 \cdot 3 \\
35.8 \\
0 \\
0 \\
10.9\end{array}$ & GW & $\begin{array}{l}\text { UK Department of Energy and } \\
\text { Climate Change [74]. }\end{array}$ \\
\hline
\end{tabular}




\begin{tabular}{|c|c|c|c|c|}
\hline & $\begin{array}{c}\text { Onshore Wind } \\
\text { Offshore Wind } \\
\text { Large Scale Solar PV }\end{array}$ & $\begin{array}{c}0 \\
4.218 \\
0\end{array}$ & & \\
\hline $\begin{array}{l}\text { Power } \\
\text { Generation } \\
\text { Technology } \\
\text { Levelised } \\
\text { Costs } \\
\text { (LCOE) }\end{array}$ & $\begin{array}{c}\text { Gas } \\
\text { Coal } \\
\text { Coal-CCS } \\
\text { Gas-CCS } \\
\text { Nuclear } \\
\text { Onshore Wind } \\
\text { Offshore Wind } \\
\text { Large Scale Solar PV }\end{array}$ & $\begin{array}{c}L=6.1, C=10.1, H=14.2 \\
L=6.7, C=9.6, H=12.5 \\
L=34.6, C=44.4, H=56.4 \\
L=34.6, C=38.4, H=43.1 \\
L=26.4, H=45.6 \\
L=19.5, C=24.1, H=29.8 \\
L=34.0, C=38.4, H=43.6 \\
L=29.6, C=31.7, \quad H=34.0\end{array}$ & f/GJ & $\begin{array}{l}\text { Triangular distributions used where } \\
\text { literature provides low }(\mathrm{L}) \text {, central } \\
\text { (C) and high }(\mathrm{H}) \text { values, uniform } \\
\text { distributions used for high / low } \\
\text { data. Sources include a range of } \\
\text { government and academic } \\
\text { references converted to } 2010 \text { base } \\
\text { year [71,75-77]. }\end{array}$ \\
\hline $\begin{array}{l}\text { Residential } \\
\text { Heating } \\
\text { Technology } \\
\text { Portfolio }\end{array}$ & $\begin{array}{l}\text { Gas Boiler } \\
\text { Elec. Resistive Heating } \\
\text { Air Source Heat Pump }\end{array}$ & $\begin{array}{c}92.8 \\
7.2 \\
0\end{array}$ & $\%$ & $\begin{array}{l}\text { UK Department of Energy and } \\
\text { Climate Change (DECC) [72]. }\end{array}$ \\
\hline $\begin{array}{l}\text { Residential } \\
\text { Heating } \\
\text { Technology } \\
\text { Costs }\end{array}$ & $\begin{array}{l}\text { Gas Boilers } \\
\text { Elec. Resistive Heating } \\
\text { Air Source Heat Pumps }\end{array}$ & $\begin{array}{c}L=2500, H=3000 \\
L=1750, H=4025 \\
L=8400, H=10500\end{array}$ & $f$ & $\begin{array}{l}\text { Uniform distributions used to span } \\
\text { range of estimates [78]. }\end{array}$ \\
\hline $\begin{array}{l}\text { Commercial } \\
\text { Heating } \\
\text { Technology } \\
\text { Portfolio }\end{array}$ & $\begin{array}{l}\quad \text { Gas Boilers } \\
\text { Elec. Resistive Heating } \\
\text { Air Source Heat Pumps }\end{array}$ & $\begin{array}{c}87 \\
13 \\
0\end{array}$ & $\%$ & $\begin{array}{l}\text { Based on UK Department of Energy } \\
\text { and Climate Change [79] }\end{array}$ \\
\hline $\begin{array}{l}\text { Commercial } \\
\text { Heating } \\
\text { Technology } \\
\text { Costs }\end{array}$ & $\begin{array}{l}\text { Gas Boilers } \\
\text { Elec. Resistive Heating } \\
\text { Air Source Heat Pumps }\end{array}$ & $\begin{array}{l}18142 \\
42653 \\
29975\end{array}$ & $f$ & $\begin{array}{l}\text { Based on NERA and AEA [78]. } \\
\text { Report only gives a single value for } \\
\text { representative heat pump } \\
\text { installation so no ranges used }\end{array}$ \\
\hline $\begin{array}{l}\text { Road } \\
\text { Transport } \\
\text { Technology } \\
\text { Portfolio }\end{array}$ & $\begin{array}{l}\text { Fossil Fuel Vehicles } \\
\text { Electric Vehicles }\end{array}$ & $\begin{array}{c}100 \\
0\end{array}$ & $\%$ & $\begin{array}{l}\text { Electric vehicle sales in the UK were } \\
\text { less than } 0.1 \% \text { of annual sales in } \\
2012 \text { [80], so it can be assumed that } \\
\text { as a fraction of the road fleet } \\
\text { composition they were negligible in } \\
2010 \text {. }\end{array}$ \\
\hline $\begin{array}{l}\text { Road } \\
\text { Transport } \\
\text { Technology } \\
\text { Costs }\end{array}$ & $\begin{array}{l}\text { Fossil Fuel Vehicles } \\
\text { Electric Vehicles }\end{array}$ & $\begin{array}{c}14330 \\
L=25620, C=20490, H=59440\end{array}$ & $f$ & $\begin{array}{l}\text { Representative values for C/D class } \\
\text { vehicles, based on [81]. }\end{array}$ \\
\hline
\end{tabular}


Table 5-Key driving assumptions

\begin{tabular}{|c|c|c|c|c|}
\hline Parameter & Sub-Parameter & $\begin{array}{c}\text { Value } \\
\text { (L=Low, } C=\text { Central, } \mathrm{H}=\text { high) }\end{array}$ & Units & Notes \\
\hline $\begin{array}{l}\text { Energy } \\
\text { Service } \\
\text { Demand } \\
\text { Growth }\end{array}$ & $\begin{array}{c}\text { Residential } \\
\text { Commercial } \\
\text { Industrial } \\
\text { Transport (Road) } \\
\text { Transport (Air) } \\
\text { Transport (Rail) } \\
\text { Transport (Marine) }\end{array}$ & Variable (see Section 2.2) & $\% / y e a r$ & $\begin{array}{l}\text { Demand drivers in BLUE for this } \\
\text { study have been chosen to mimic } \\
\text { the baseline projections used by the } \\
\text { UK Department of Energy and } \\
\text { Climate Change (DECC) in the } \\
\text { government's latest carbon budget } \\
\text { assessment [82]. } \\
\text { Residential demand makes } \\
\text { assumptions about population } \\
\text { growth, the number of new } \\
\text { households, house demolition rates, } \\
\text { and also heat demand in a climate } \\
\text { change influenced world. } \\
\text { Commercial and Industrial demand } \\
\text { assumptions reflect the government } \\
\text { view on future economic growth. } \\
\text { Transport demand drivers are } \\
\text { aligned with UK Department for } \\
\text { Transport (DfT) central projections. }\end{array}$ \\
\hline $\begin{array}{l}\text { Fossil Fuel } \\
\text { Price }\end{array}$ & $\begin{array}{l}\text { Oil } \\
\text { Coal } \\
\text { Gas }\end{array}$ & Variable (see Section 2.2) & $\% /$ year & $\begin{array}{l}\text { Triangular distributions through } \\
\text { time which reflect UK Department of } \\
\text { Energy and Climate Change (DECC) } \\
\text { projections [83]. }\end{array}$ \\
\hline $\begin{array}{l}\text { Power } \\
\text { Generation } \\
\text { Technology } \\
\text { Cost Change }\end{array}$ & $\begin{array}{c}\text { Gas } \\
\text { Coal } \\
\text { Coal-CCS } \\
\text { Gas-CCS } \\
\text { Nuclear } \\
\text { Onshore Wind } \\
\text { Offshore Wind } \\
\text { Large Scale Solar PV }\end{array}$ & 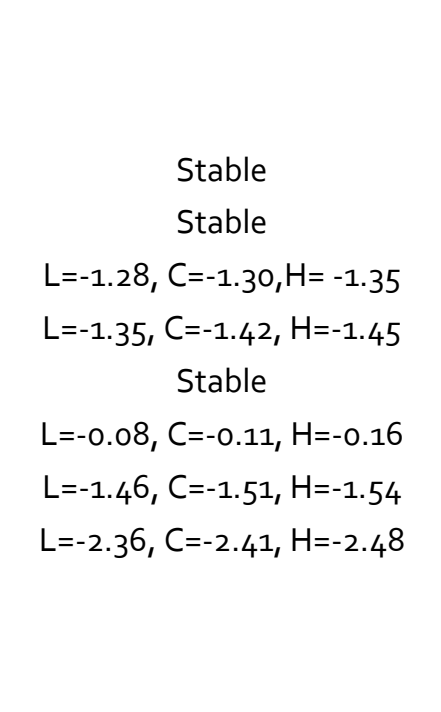 & $\% / y e a r$ & $\begin{array}{l}\text { For CCS and renewable options, } \\
\text { technology costs fall to the } 2030 \\
\text { levels found in the literature and } \\
\text { then remain at } 2030 \text { levels out to } \\
2050 \text {. Implied cost reduction } \\
\text { trajectories based on } \\
\text { high/central/low values in DECC } 2013 \\
\text { [71]. } \\
\text { Costs for nuclear and conventional } \\
\text { fossil thermal power stations are } \\
\text { modelled as stable in real terms. } \\
\text { There is large uncertainty over the } \\
\text { cost of new nuclear power in the UK } \\
\text { (captured in Table } 4 \text { inputs) and no } \\
\text { empirical evidence that costs fall } \\
\text { with increased deployment [84]. }\end{array}$ \\
\hline $\begin{array}{l}\text { Residential } \\
\text { and } \\
\text { Commercial } \\
\text { Heating } \\
\text { Technology } \\
\text { Cost Change }\end{array}$ & $\begin{array}{l}\text { Gas Boilers } \\
\text { Elec. Resistive Heating } \\
\text { Air Source Heat Pumps }\end{array}$ & $\begin{array}{c}\text { Stable } \\
\text { Stable } \\
\mathrm{L}=-0.3, \mathrm{C}=-0.6, \mathrm{H}=-1.0\end{array}$ & $\% / y e a r$ & $\begin{array}{l}\text { Gas boiler and electric resistive } \\
\text { heating are modelled as stable in } \\
\text { real terms. Range of heat pump cost } \\
\text { reduction potential based on } \\
\text { industry literature produced for } \\
\text { DECC and the UK Committee on } \\
\text { Climate Change (CCC) }[85,86] \text {. }\end{array}$ \\
\hline
\end{tabular}




\begin{tabular}{|l|c|l|l|l|}
\hline & & & $\begin{array}{l}\text { Modelled cost changes plateau post- } \\
\text { 2030. Fossil fuel vehicle costs are } \\
\text { expected to increase as engines and } \\
\text { exhaust systems become more } \\
\text { complex in search of efficiency gains } \\
\text { Road } \\
\begin{array}{l}\text { Transport } \\
\text { Technology } \\
\text { Cost Change }\end{array}\end{array} \quad \begin{array}{c}\text { Fossil Fuel Vehicles } \\
\text { Electric Vehicles } \\
\text { electric vehicle costs are expected to } \\
\text { fall, driven by improvements in } \\
\text { battery costs. Costs based on } \\
\text { industry literature [81]. }\end{array}$ \\
\hline
\end{tabular}

\subsection{Analysis Approach}

This paper explores the effect of landscape and actor inertia via an assessment of UK compliance against the national climate target, which is an $80 \%$ reduction in GHG emissions by 2050 (from 1990 levels) from all economic sectors, including shipping and aviation [87]. In total, 16 scenarios are explored (described below and summarized in Section 3.3), comprising of:

- 4 potential landscape conditions, such as government policy stringency and lifestyle change; and

- 4 different behavioural assumptions for actor behaviour;

Technology diffusion, energy use and overall $\mathrm{CO}_{2}$ emissions for the UK are computed for each scenario. BLUE is run in a stochastic Monte Carlo fashion with 500 iterations per scenario in order to capture the degree of uncertainty arising from the use of the probabilistic input variables.

\subsection{Landscape conditions}

The landscape in socio-technical studies contains the macro-scale contextual conditions for the transition, and can include factors as diverse as "oil prices, economic growth, wars, emigration, broad political coalitions, cultural and normative values, environmental problems" [26]. In this paper, we operationalise "landscape inertia" in our model as a dynamic element by testing the effects of synergistic changes to carbon pricing and societal preferences.

A government imposed carbon price is used as a proxy for specific policy instruments and represents the level of government action taken to mitigate emissions. Carbon prices start low and are increased over time, following one of three UK government Department of Energy and Climate Change (DECC) trajectories to 2050 [88]. The increasing price of carbon is reflected in how the costs of technology options are perceived by the model actors, and feeds through to their decision choice framework (as described earlier in Section 2.2).

As well as the level of government ambition, societal preferences and lifestyles are also important to understand landscape inertia. The default demand pathway for the UK used in BLUE (see Table 5) already incorporates a falling per capita heat demand 
(as a result of the uptake of thermal efficiency measures in buildings) as well as stable per capita demand for electrical appliances. Transport projections on the other hand, follow UK Department for Transport (DfT) projections and imply large increases in personal travel budgets. DfT projects that road transport demand per capita will double by 2050, and that air travel demand per person will quadruple. Questioning the assumptions around personal mobility in therefore is a key area to explore from a lifestyle perspective.

In the UK, $68 \%$ of total journeys are made by car [89] but almost $40 \%$ of these are over distances of less than $5 \mathrm{~km}$ [90]. The spatial planning of denser settlements $(>50$ people/ha) with convenient access to services and employment hubs could represent a key strategy for reducing dependence on car commutes [91], as well as increasing the uptake of mass transit and non-motorised transport options [92]. Air travel demand is the fastest growing source of transport emissions in developed countries like the UK [93]. Aviation is recognised as a difficult to decarbonise sector with relatively few technical mitigation options, so future social attitudes towards air travel may also be key to influencing compliance with climate targets. We explore here the potential for lifestyle choices to modify end use energy demand away from the default UK government pathway in three key areas:

- Growth in non-motorised transport to between 10 and $20 \%$ of travel demand

- Stabilisation of road travel demands at 2030 levels (allows for a $~ 30 \%$ increase in per capita demand relative to 2010)

- Stabilisation of air travel demands at 2020 levels (allows for a 50\% increase in per capita demand relative to 2010)

The dimensions explored for landscape conditions are summarised in Table 6. Each setting L1 - L4 includes a mixture of both lifestyle change and policy factors, on the basis that political decisions are likely to flow from a social mandate for action. It is difficult to imagine a future where a democratically elected government is able to successfully impose strong carbon taxes on a population that is not in favour of environmental action. Likewise, the development of a strong social consciousness driving major changes to consumption and lifestyles appears unlikely to spontaneously emerge in a market based society in the absence of any price signals. Therefore, for the purposes of our analysis in this paper, strong government action on emissions mitigation and strong lifestyle change elements are grouped together, while weaker government action and less profound changes to lifestyle are similarly combined.

At one extreme is a case where the UK government's "high" trajectory for $\mathrm{CO}_{2}$ pricing is followed, accompanied by significant changes in lifestyle (L4) and at the other is a case where there is no government policy in support of low carbon technologies and no change from baseline projections for end use energy demand (L1). 
Table 6 - Exploratory dimensions for landscape conditions

\begin{tabular}{|c|c|c|}
\hline Test Case & $\begin{array}{c}\text { Carbon Tax } \\
\text { Trajectory }\end{array}$ & Lifestyle Change \\
\hline L1 & No carbon tax & No change from baseline DECC projections \\
\hline L2 & $\begin{array}{c} \pm 100 / t C O 2 ~ b y \\
2050\end{array}$ & Increase in non-motorised transport \\
\hline L3 & $\begin{array}{c} \pm 200 / \mathrm{tCO}_{2} \text { by } \\
2050\end{array}$ & $\begin{array}{c}\text { Increase in non-motorised transport, and } \\
\text { stabilisation of road travel demand }\end{array}$ \\
\hline $\mathrm{L} 4$ & $\begin{array}{c} \pm 300 / \mathrm{tCO} 2 \text { by } \\
2050\end{array}$ & $\begin{array}{c}\text { Non-motorised transport, } \\
\text { stabilisation of road travel demand, and } \\
\text { stabilisation of air travel demand }\end{array}$ \\
\hline
\end{tabular}

\subsection{Behavioural settings}

To explore actor inertia, a range of possible micro-economic behaviours and non-cost barriers are explored. These are summarised in Table 7. At one extreme is cost optimising behaviour with a social planning perspective (A4), at the other is a case with parameters for exploring bounded rationality and non-cost barriers included (A1). Demand elasticities are represented as triangular distributions, based on an extensive review found in Pye et al. [69]. Market heterogeneity explores a range of settings described earlier in Section 2.3.4. Social discount rates used in EU policy assessment are typically in the range of $3-6 \%$ [94]. The UK government recommends a social discount rate of 3.5\% [95]. Models often use private discount rates for technology investment evaluation that approximate the typical financial cost of capital available to the actor e.g. 9-17\% [96]. A detailed discussion on the selection of appropriate hurdle rates in long term energy economic modelling is beyond the scope of this paper [97]. However, ranges that reflect two extremes, both the societal and the individual perspective (when generalised across the whole population) are explored. 
Table 7 - Exploratory dimensions for actor behaviour ( $\mathrm{L}=\mathrm{Low}, \mathrm{C}=\mathrm{Central}, \mathrm{H}=\mathrm{High}$ )

\begin{tabular}{|c|c|c|c|c|c|c|c|}
\hline Test Case & Description & $\begin{array}{l}\text { Behavioural } \\
\text { Parameter }\end{array}$ & Residential & $\begin{array}{c}\text { Road } \\
\text { Transport }\end{array}$ & Power & Commercial & Industrial \\
\hline \multirow{7}{*}{$\mathrm{A}_{4}$} & \multirow{7}{*}{$\begin{array}{l}\text { Cost optimising } \\
\text { behaviour, } \\
\text { social planning } \\
\text { perspective }\end{array}$} & & $L=-0.1$ & $L=-0.15$ & & $L=-0.01$ & $L=-0.01$ \\
\hline & & $\begin{array}{l}\text { Demand } \\
\text { elasticities }(\boldsymbol{e})\end{array}$ & $C=-0.25$ & $C=-0.30$ & & $C=-0.1$ & $C=-0.03$ \\
\hline & & & $H=-0.40$ & $H=-0.50$ & & $H=-0.15$ & $\mathrm{H}=-0.05$ \\
\hline & & $\begin{array}{c}\text { Market } \\
\text { heterogeneity } \\
(\boldsymbol{v})\end{array}$ & \multicolumn{5}{|c|}{$20-50$} \\
\hline & & $\begin{array}{l}\text { Intangible costs } \\
\text { (i) }\end{array}$ & \multicolumn{2}{|c|}{0} & & \multicolumn{2}{|c|}{0} \\
\hline & & $\begin{array}{l}\text { Hurdle rate } \\
\qquad(\boldsymbol{r})\end{array}$ & \multicolumn{2}{|c|}{$3-6 \%$} & $\begin{array}{l}\text { Implicit in } \\
\text { LCOE (see }\end{array}$ & \multicolumn{2}{|c|}{$3-6 \%$} \\
\hline & & $\begin{array}{l}\text { Retrofitting / } \\
\text { replacement } \\
\text { rate }(b)\end{array}$ & $\begin{array}{l}\text { Every } 15 \\
\text { years }\end{array}$ & Every 10 years & $\begin{array}{l}\text { Technology } \\
\text { specific, } \\
\text { based on } \\
\text { [71] }\end{array}$ & $\begin{array}{l}\text { Every } 15 \\
\text { years }\end{array}$ & $\begin{array}{c}\text { Every } 20 \\
\text { years }\end{array}$ \\
\hline \multirow{7}{*}{$A_{3}$} & \multirow{7}{*}{$\begin{array}{l}\text { Strong price } \\
\text { sensitivity, } \\
\text { social planning } \\
\text { perspective }\end{array}$} & & $L=-0.1$ & $L=-0.15$ & & $L=-0.01$ & $L=-0.01$ \\
\hline & & elasticities (e) & $C=-0.25$ & $C=-0.30$ & & $C=-0.1$ & $C=-0.03$ \\
\hline & & & $H=-0.40$ & $H=-0.50$ & & $H=-0.15$ & $H=-0.05$ \\
\hline & & $\begin{array}{c}\text { Market } \\
\text { heterogeneity } \\
(v)\end{array}$ & \multicolumn{5}{|c|}{$10-19$} \\
\hline & & $\begin{array}{l}\text { Intangible costs } \\
\text { (i) }\end{array}$ & \multicolumn{2}{|c|}{0} & & \multicolumn{2}{|c|}{0} \\
\hline & & $\begin{array}{l}\text { Hurdle rate } \\
\qquad(\boldsymbol{r})\end{array}$ & \multicolumn{2}{|c|}{$3-6 \%$} & $\begin{array}{l}\text { Implicit in } \\
\text { LCOE (see } \\
\text { Table 4) }\end{array}$ & \multicolumn{2}{|c|}{$3-6 \%$} \\
\hline & & $\begin{array}{l}\text { Retrofitting / } \\
\text { replacement } \\
\text { rate }(b)\end{array}$ & $\begin{array}{c}\text { Every } 15 \\
\text { years }\end{array}$ & Every 10 years & $\begin{array}{l}\text { Technology } \\
\text { specific, } \\
\text { based on } \\
\text { [71] }\end{array}$ & $\begin{array}{l}\text { Every } 15 \\
\text { years }\end{array}$ & $\begin{array}{c}\text { Every } 20 \\
\text { years }\end{array}$ \\
\hline \multirow{5}{*}{$\mathrm{A}_{2}$} & \multirow{5}{*}{$\begin{array}{l}\text { Partial price } \\
\text { sensitivity, } \\
\text { intangible } \\
\text { costs, social } \\
\text { planning } \\
\text { perspective }\end{array}$} & Demand & $L=-0.1$ & $L=-0.15$ & & $L=-0.01$ & $L=-0.01$ \\
\hline & & elasticities (e) & $C=-0.25$ & $C=-0.30$ & - & $C=-0.1$ & $C=-0.03$ \\
\hline & & & $\mathrm{H}=-0.40$ & $\mathrm{H}=-0.50$ & & $H=-0.15$ & $\mathrm{H}=-0.05$ \\
\hline & & $\begin{array}{c}\text { Market } \\
\text { heterogeneity } \\
(v)\end{array}$ & \multicolumn{5}{|c|}{$5-9$} \\
\hline & & $\begin{array}{l}\text { Intangible costs } \\
\text { (i) }\end{array}$ & $\begin{array}{l}\text { Air Source } \\
\text { Heat Pumps } \\
\begin{array}{c}\text { [98] } \\
L=200 \\
H=480\end{array}\end{array}$ & $\begin{array}{l}\text { UK Plug-In } \\
\text { Vehicle Grant } \\
\text { at the time of } \\
\text { writing is } \\
£ 5000\end{array}$ & - & $\begin{array}{c}\text { Air Source } \\
\text { Heat Pumps } \\
\begin{array}{c}\text { [98] } \\
L=200 \\
H=480\end{array}\end{array}$ & - \\
\hline
\end{tabular}




\begin{tabular}{|c|c|c|c|c|c|c|c|}
\hline & & $\begin{array}{l}\text { Hurdle rate } \\
\qquad(\boldsymbol{r})\end{array}$ & & $6 \%$ & $\begin{array}{l}\text { Implicit in } \\
\text { LCOE (see }\end{array}$ & & \\
\hline & & $\begin{array}{l}\text { Retrofitting / } \\
\text { replacement } \\
\text { rate }(b)\end{array}$ & $\begin{array}{l}\text { Every } 15 \\
\text { years }\end{array}$ & Every 10 years & $\begin{array}{c}\text { Technology } \\
\text { specific, } \\
\text { based on } \\
{[71]}\end{array}$ & $\begin{array}{l}\text { Every } 15 \\
\text { years }\end{array}$ & $\begin{array}{c}\text { Every } 20 \\
\text { years }\end{array}$ \\
\hline \multirow{5}{*}{$\mathrm{A}_{1}$} & \multirow{5}{*}{$\begin{array}{c}\text { Partial price } \\
\text { sensitivity, } \\
\text { intangible } \\
\text { costs, private } \\
\text { discounting }\end{array}$} & $\begin{array}{c}\text { Demand } \\
\text { elasticities }(\boldsymbol{e})\end{array}$ & $\begin{array}{l}L=-0.1 \\
C=-0.25 \\
H=-0.40\end{array}$ & $\begin{array}{l}L=-0.15 \\
C=-0.30 \\
H=-0.50\end{array}$ & - & $\begin{array}{c}L=-0.01 \\
C=-0.1 \\
H=-0.15\end{array}$ & $\begin{array}{l}L=-0.01 \\
C=-0.03 \\
H=-0.05\end{array}$ \\
\hline & & $\begin{array}{c}\text { Market } \\
\text { heterogeneity } \\
(\boldsymbol{v})\end{array}$ & \multicolumn{5}{|c|}{$5-9$} \\
\hline & & $\begin{array}{l}\text { Intangible costs } \\
\text { (i) }\end{array}$ & $\begin{array}{c}\text { Air Source } \\
\text { Heat Pumps } \\
\begin{array}{c}{[98]} \\
L=200 \\
H=480\end{array}\end{array}$ & $\begin{array}{l}\text { UK Plug-In } \\
\text { Vehicle Grant } \\
\text { at the time of } \\
\text { writing is } \\
£ 5000\end{array}$ & - & \multicolumn{2}{|c|}{0} \\
\hline & & $\begin{array}{l}\text { Hurdle rate } \\
\qquad(\boldsymbol{r})\end{array}$ & \multicolumn{2}{|c|}{$9-17 \%$} & $\begin{array}{l}\text { Implicit in } \\
\text { LCOE (see } \\
\text { Table 4) }\end{array}$ & \multicolumn{2}{|c|}{$9-17 \%$} \\
\hline & & $\begin{array}{l}\text { Retrofitting / } \\
\text { replacement } \\
\text { rate }(b)\end{array}$ & $\begin{array}{l}\text { Every } 15 \\
\text { years }\end{array}$ & Every 10 years & $\begin{array}{c}\text { Technology } \\
\text { specific, } \\
\text { based on } \\
{[71]}\end{array}$ & $\begin{array}{l}\text { Every } 15 \\
\text { years }\end{array}$ & $\begin{array}{c}\text { Every } 20 \\
\text { years }\end{array}$ \\
\hline
\end{tabular}




\subsection{Scenario summary}

An ensemble of 16 scenarios, illustrated in Figure 7, were assessed by combining the landscape and behavioural dimensions discussed above. To explore the uncertainties in the input data, each scenario set was run 500 times using Monte Carlo simulation.

Figure 7 - Full set of exploratory scenarios in BLUE

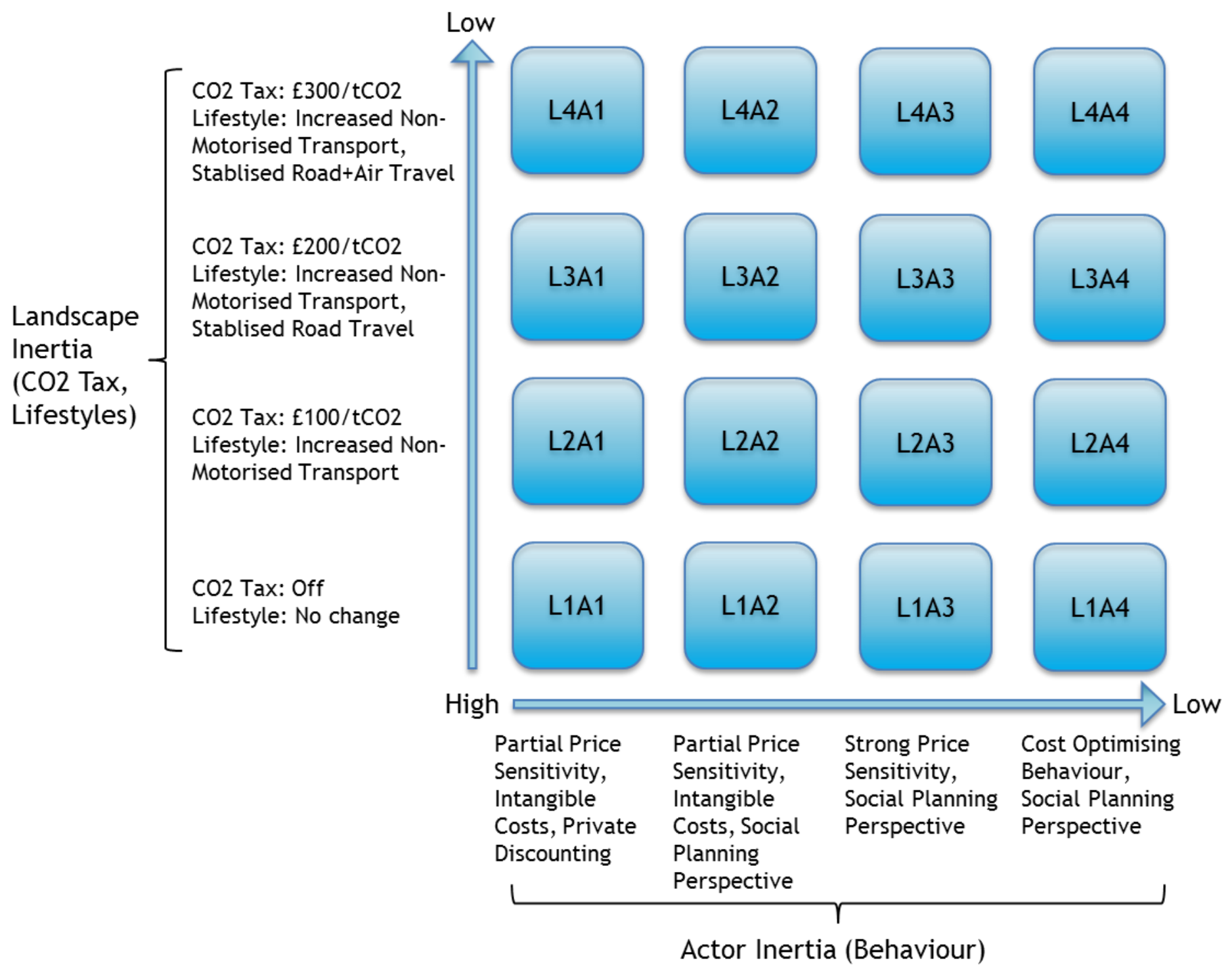




\subsection{Results}

4.1 Technological transitions in key sectors

Selected results are illustrated below for technological change in the power, buildings, and road transport sectors. As noted in Section 2.3, these are the main energy system sectors under which past policy analyses have concluded that the deepest transformations must occur in the UK context.

\subsubsection{Power sector}

Figure 8 shows four key transitions from the simulated scenario set. These are effectively the four corners of the full 16-scenario diagram shown above in Section 3.3. The lower two quadrants $\left(\mathbf{L}_{1} \mathbf{A}_{1}, \mathbf{L} \mathbf{1} \mathbf{A}_{4}\right)$ represent technological change under conditions of high landscape inertia i.e. no carbon price signal, and no lifestyle change. The upper two quadrants, (L4A1, L4A4) show a power sector transition under conditions of low landscape inertia i.e. a strong carbon price signal, with significant lifestyle change. The scenarios to the left hand side of the chart ( $\mathbf{L}_{\mathbf{4}} \mathbf{A}_{\mathbf{1}}$, L1A1) exhibit the effects of high actor inertia. Actors display partial price sensitivity, perceive intangible costs to unfamiliar technologies, and use a private discount rate for evaluating their options. Those scenarios on the right of the chart ( $\left.\mathbf{L}_{\mathbf{4}} \mathbf{A}_{\mathbf{4}}, \mathrm{L}_{\mathbf{1}} \mathbf{A}_{\mathbf{4}}\right)$ illustrate outcomes under low actor inertia. In this case, actors exhibit cost optimising behaviour, ignore intangible costs, and take a social planning perspective on discounting the future.

The most obvious difference between the high landscape inertia and low landscape inertia scenarios is the change in the deployment of low carbon generation technologies. Under high landscape inertia scenarios (the L1 set), which have no carbon price signal, the power sector becomes dominated by a mixture of coal and gas plant. Under low landscape inertia scenarios (the $L \mathbf{4}$ set), which have the pollution externality from fossil fuel use subjected to a high carbon tax, coal loses significant market share and there is a shift to both natural gas and a large fraction of low carbon energy sources.

Actor inertia can also be seen to exert an effect on technology selection. If we focus first on the L1 scenario set, it can be seen that under conditions where actors display cost optimal choice behaviour and use a social discount rate for investment analysis (L1A4) a large fraction of the 2010 coal plant is displaced by gas in 2050. In contrast, it can be seen that under conditions where actors display a lower propensity to cost optimisation and take a private perspective on discounting the future (L1A1), coal retains significant market share throughout the time horizon.

The $\mathbf{L} \mathbf{4}$ scenario set also shows important differences arising from the effects of actor inertia. With cost optimising actor behaviour and a social planning perspective (L4A4), coal becomes almost completely eliminated from the generation portfolio as early as the mid 2020's, the transition to renewable energy happens very late in the time horizon (around 2045), and comes mostly from solar power. In the scenario 
where actors display a less pronounced sensitivity to prices, and where a private discount rate is used ( $\left.\mathbf{L}_{\mathbf{4}} \mathbf{A} \mathbf{1}\right)$, the decline in coal is much less pronounced. The transition to low carbon energy also begins much earlier (around 2030), and comes from a wider set of sources, including solar and onshore wind.

Figure 8 - Power sector transitions (median values)

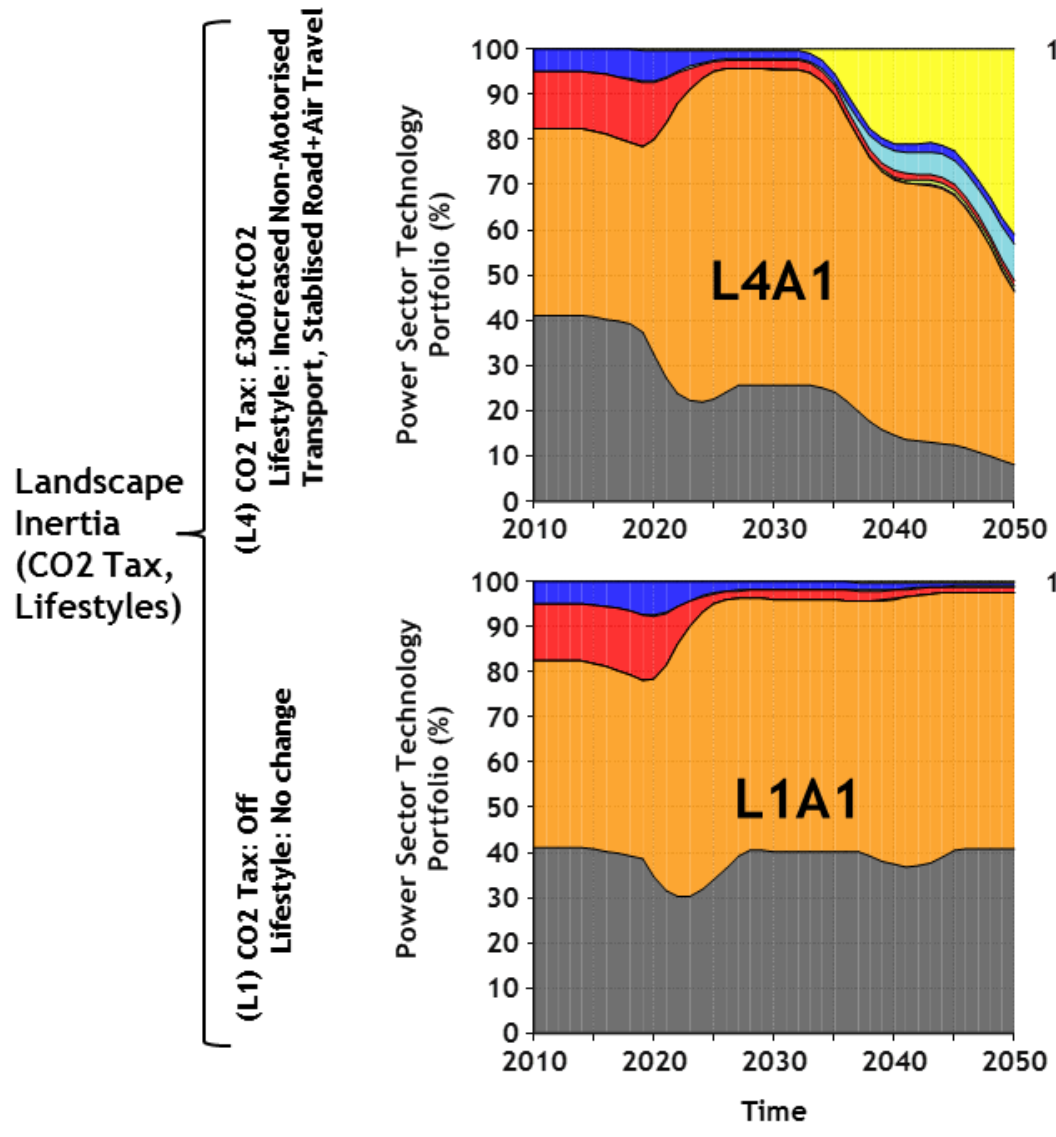

(A1) Partial Price Sensitivity, Intangible Costs, Private Discounting
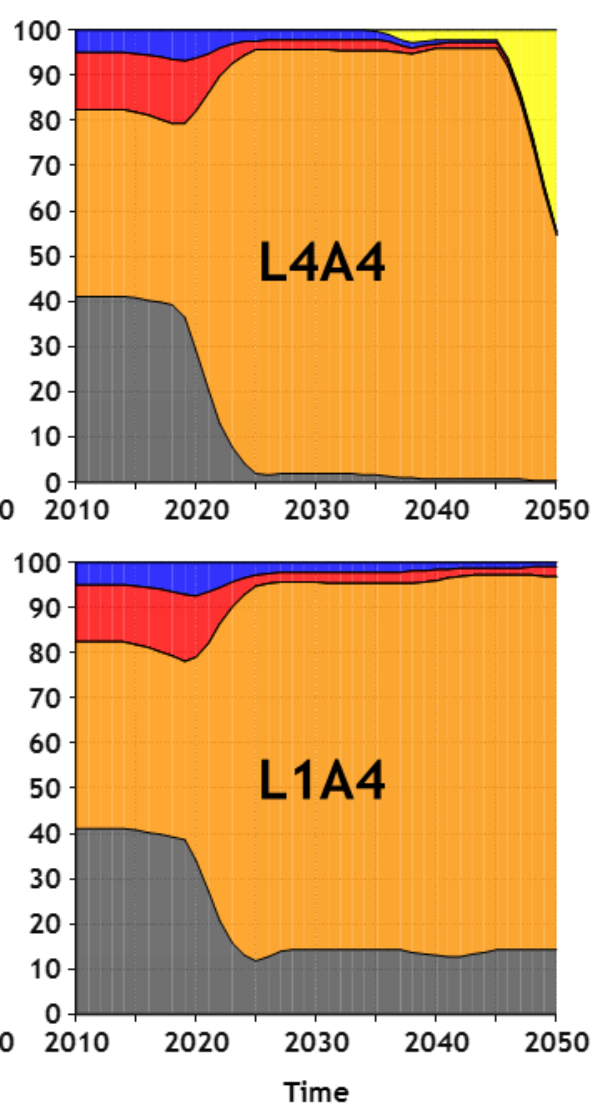

(A4) Cost Optimising Behaviour, Social Planning Perspective

Actor Inertia (Behaviour)

\subsubsection{Buildings sector}

Figure 9 highlights changes found in residential heating technologies in a fourquadrant chart that shows key scenarios from the full 16-scenario set. As with the power sector chart described above in Section 4.1.1, these have been selected to demonstrate the combined effects of both high and low landscape inertia, and high and low actor inertia.

It can be seen that in the scenarios with high landscape inertia, where no price is put on GHG emissions from fossil fuels (the L1 set), the residential heating sector remains largely dominated by gas boilers. Electrification is minimal and no heat pumps are deployed. On the other hand, under the scenarios with low landscape inertia (the L4 
set), a large fraction of heat demand (around 60\%) becomes electrified. This is driven by both the progressive decarbonisation of the electricity sector as well as the increasing costs of using gas due to the strong carbon tax found in these scenarios.

The influence of actor behavioural parameters can be seen prominently in the scenarios that employ significant electrification of heat (the $L_{4}$ set). Under conditions where actors take a cost optimising, social planning perspective, with no intangible costs ( $\left.\mathbf{L}_{\mathbf{4}} \mathbf{A}_{\mathbf{4}}\right)$, most electrification of residential heating occurs with heat pumps. In contrast, under conditions where actors display more heterogeneous choice behaviour, consider intangible costs, and take a private discounting perspective, most electrification occurs with direct electric heating. This difference is likely to arise as a result of the capital cost differential between heat pumps and direct electric heating (see Section 2.3). The inclusion of intangible costs and a high, private discount rate, serves to make heat pumps appear relatively less attractive to the residential sector actor.

Figure 9-Residential buildings sector transitions (median values)

Landscape Inertia (CO2 Tax, Lifestyles)

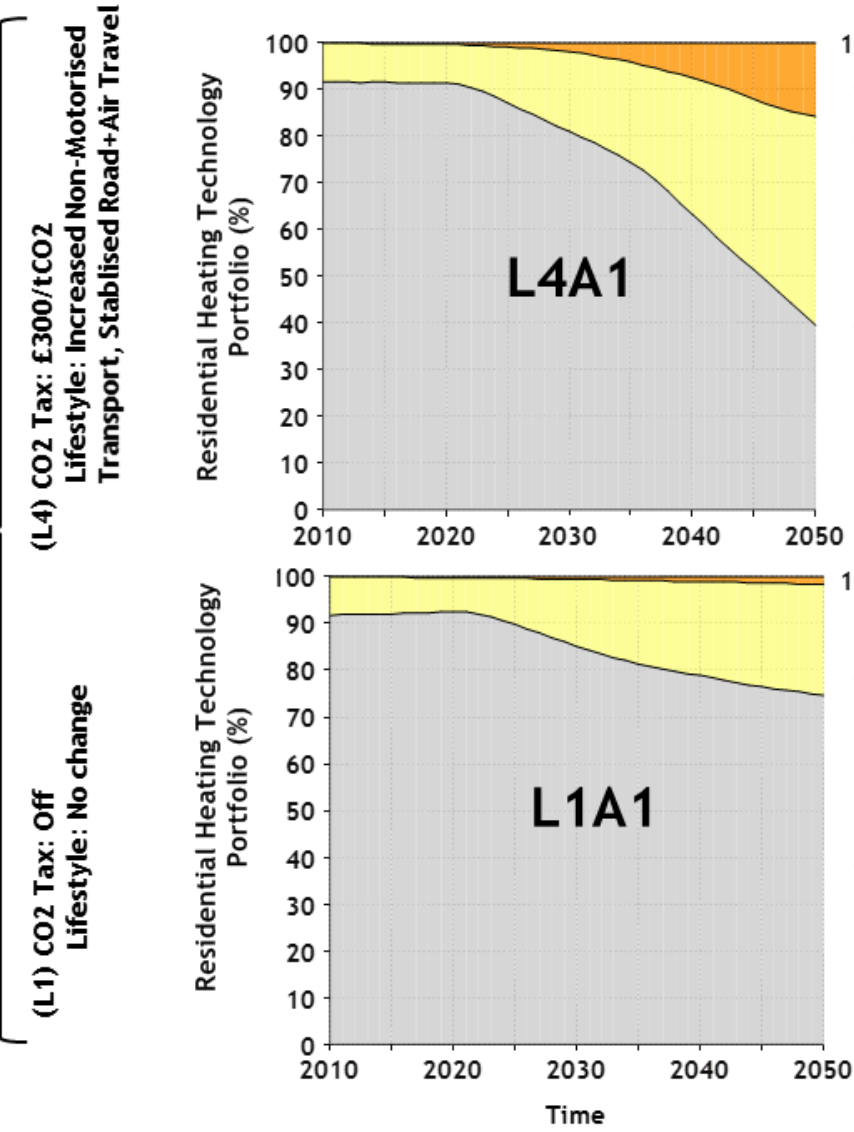

(A1) Partial Price Sensitivity, Intangible Costs, Private Discounting
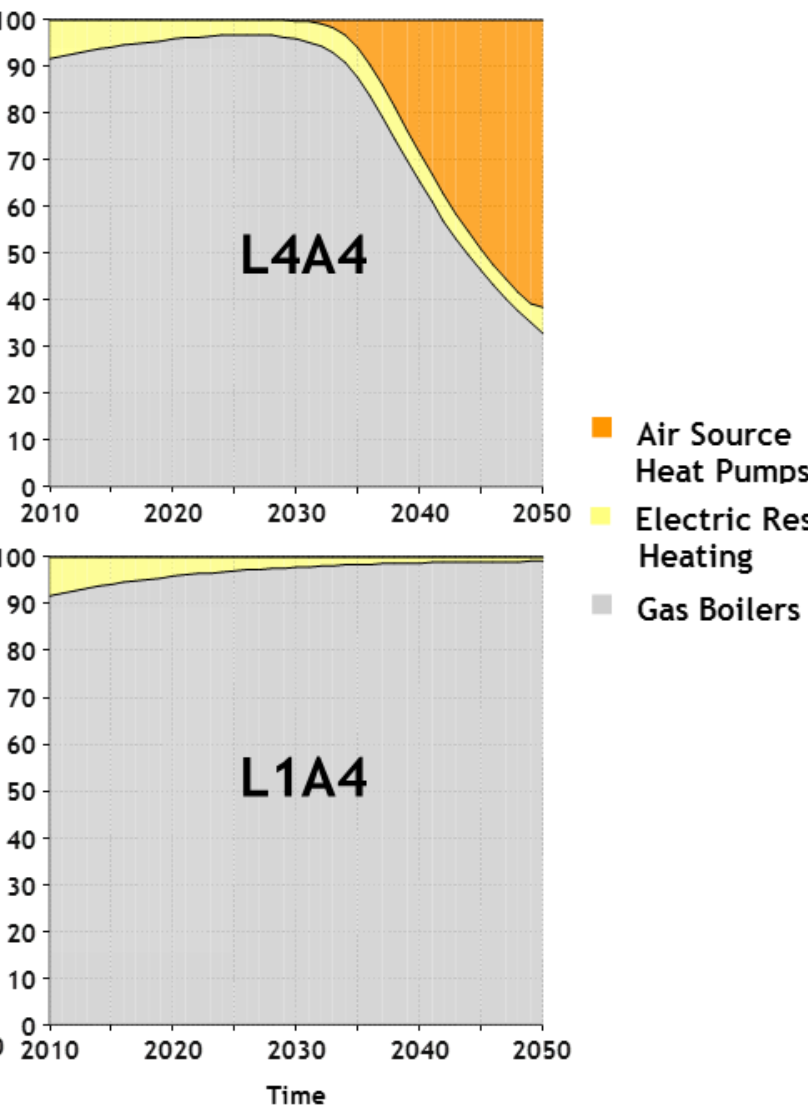

(A4) Cost Optimising Behaviour, Social Planning Perspective 


\subsubsection{Transport sector}

Figure 10 illustrates four scenarios for the road transport fleet, occurring under the same conditions as the corresponding transitions shown above for power (Section 4.1.1) and buildings (Section 4.1.2). Scenarios with high landscape inertia (the L1 set) show only minimal electrification of the vehicle fleet, while electric vehicles show substantial penetration in scenarios with low landscape inertia (the $\mathbf{L} \mathbf{4}$ set). Actor behavioural parameters have a strong effect. With actor behaviour set to be cost optimising and using a social discount rate ( $\left.\mathbf{L}_{\mathbf{4}} \mathbf{A}_{\mathbf{4}}\right)$, penetration of electric vehicles by 2050 is extremely rapid and comes to make up nearly $90 \%$ of the fleet. On the other hand, if actors are assumed to be more sensitive to non-cost variables, incur intangible costs, and use a private discount rate for assessing their choices (L4A1), electric vehicles capture a significant, but much lower market share over the same period (around 30\%). This reflects increasing actor sensitivity to up front capital costs and the increase in perceived costs.

Figure 10 - Road transport sector transitions (median values)
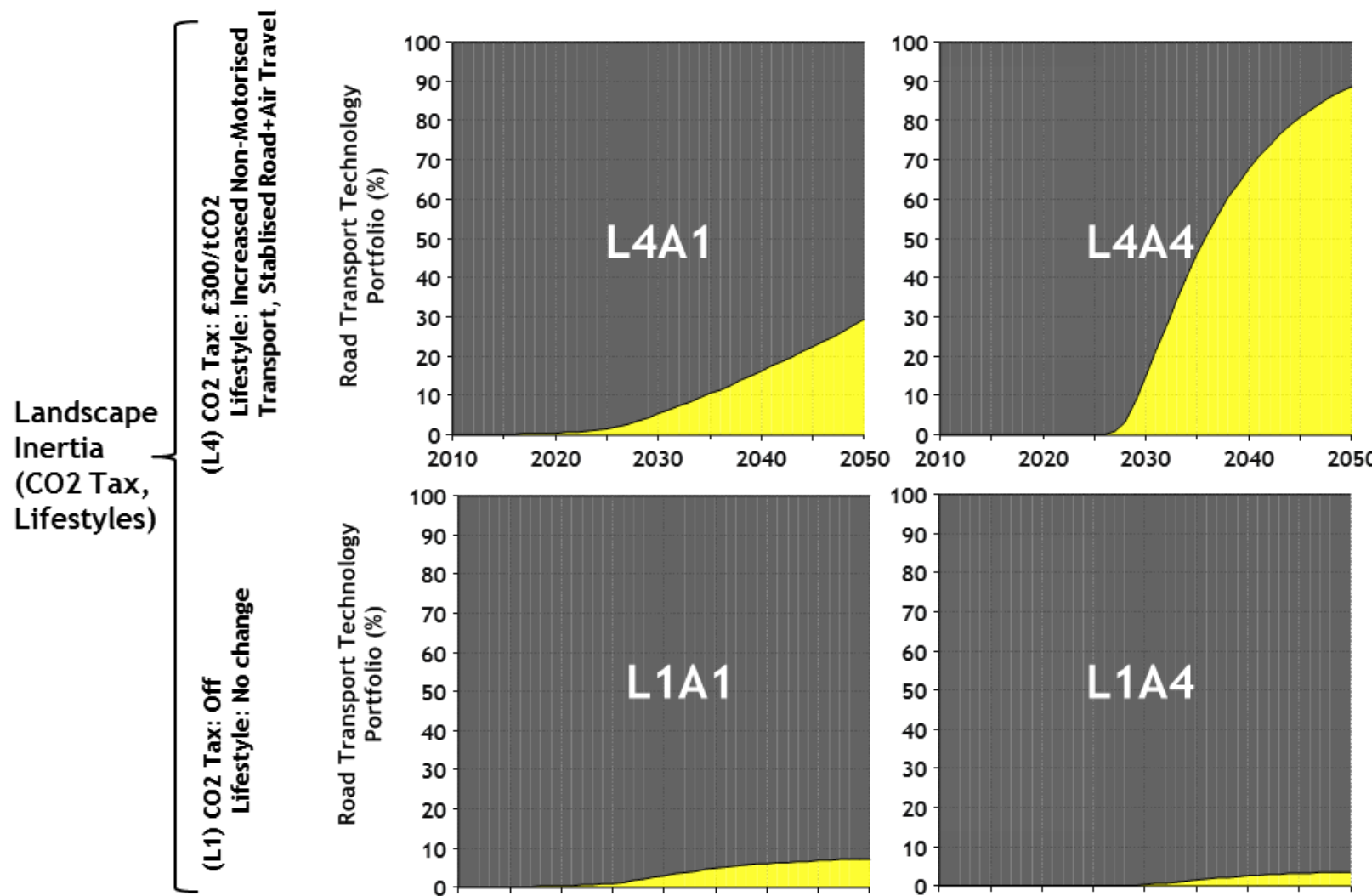

Fossil Fuel Vehicles

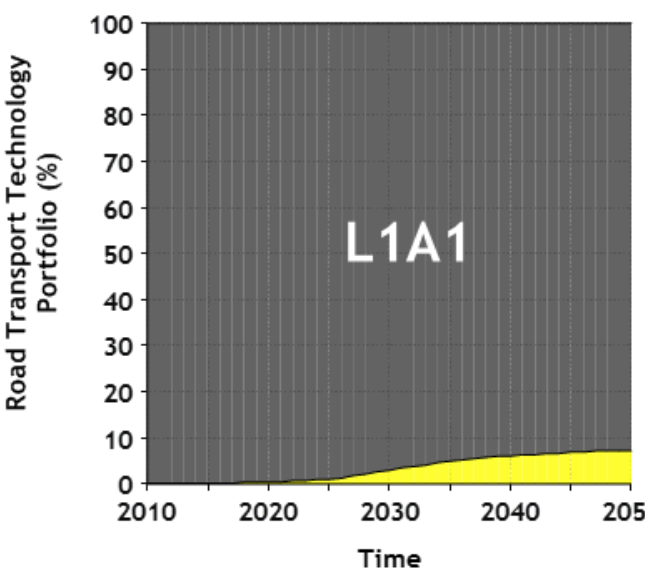

(A1) Partial Price Sensitivity, Intangible Costs, Private Discounting

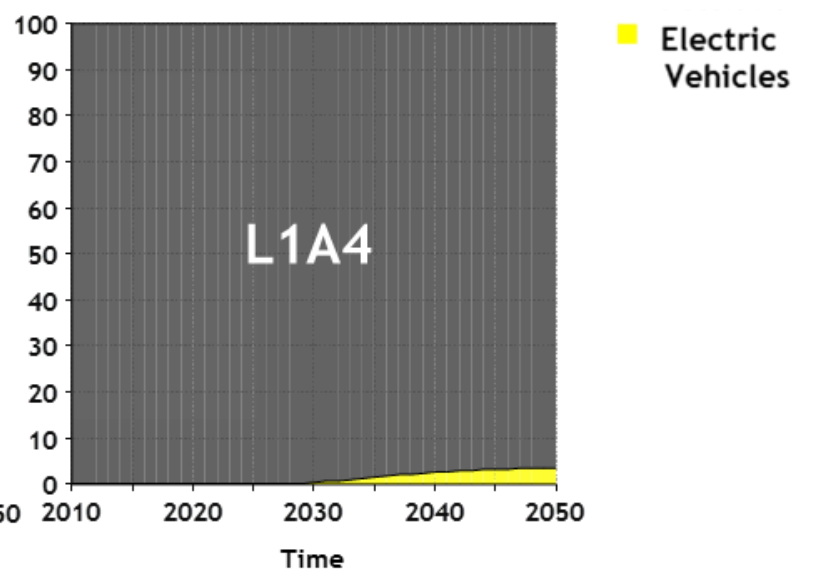

(A4) Cost Optimising Behaviour, Social Planning Perspective 


\subsection{Climate target compliance}

The ability of the energy system to meet UK climate targets for 2050 under the various scenarios explored is assessed below.

\subsubsection{Central estimates for emissions reductions}

The relationship between landscape inertia, actor inertia, and emissions reductions can be seen below in Figure 11. Each of the 16 data points plotted represents the median estimate across the 500 Monte Carlo simulations carried out for each of the 16 scenarios summarised in Section 3.3. From the chart it can be seen that under conditions representing the highest landscape inertia and the highest actor inertia (L1A1), median estimates for delivered emissions reductions are extremely low, of the order of only $2 \%$. At the other extreme, with cost optimising behaviour, a social planning perspective on discounting the future, high carbon taxes and changes to lifestyle considered, the median estimate is for a $56 \%$ reduction in emissions (L4A4).

It can be seen from Figure 11 that for achieving emissions targets, landscape inertia appears to have a much stronger effect than actor inertia. Comparing L1A1 (median $2 \%$ reduction) against $\mathrm{L}_{\mathbf{4}} \mathrm{A} \mathbf{1}$ (median $45 \%$ reduction), it can be seen that supportive landscape conditions can increase the level of climate mitigation achieved even if actor inertia is high. However, actor inertia alone can also be observed to exert a powerful effect. By comparing $\mathbf{L}_{\mathbf{4}} \mathbf{A}_{\mathbf{4}}$ (median $56 \%$ reduction) against $\mathbf{L}_{\mathbf{4}} \mathrm{A}_{\mathbf{1}}$ (median $45 \%$ reduction), it can be seen that increasing actor inertia does impose a noticeable drag on mitigation efforts, even when landscape conditions are otherwise favourable.

Figure 11 - Median estimated $\mathrm{CO}_{2}$ reductions achieved by 2050

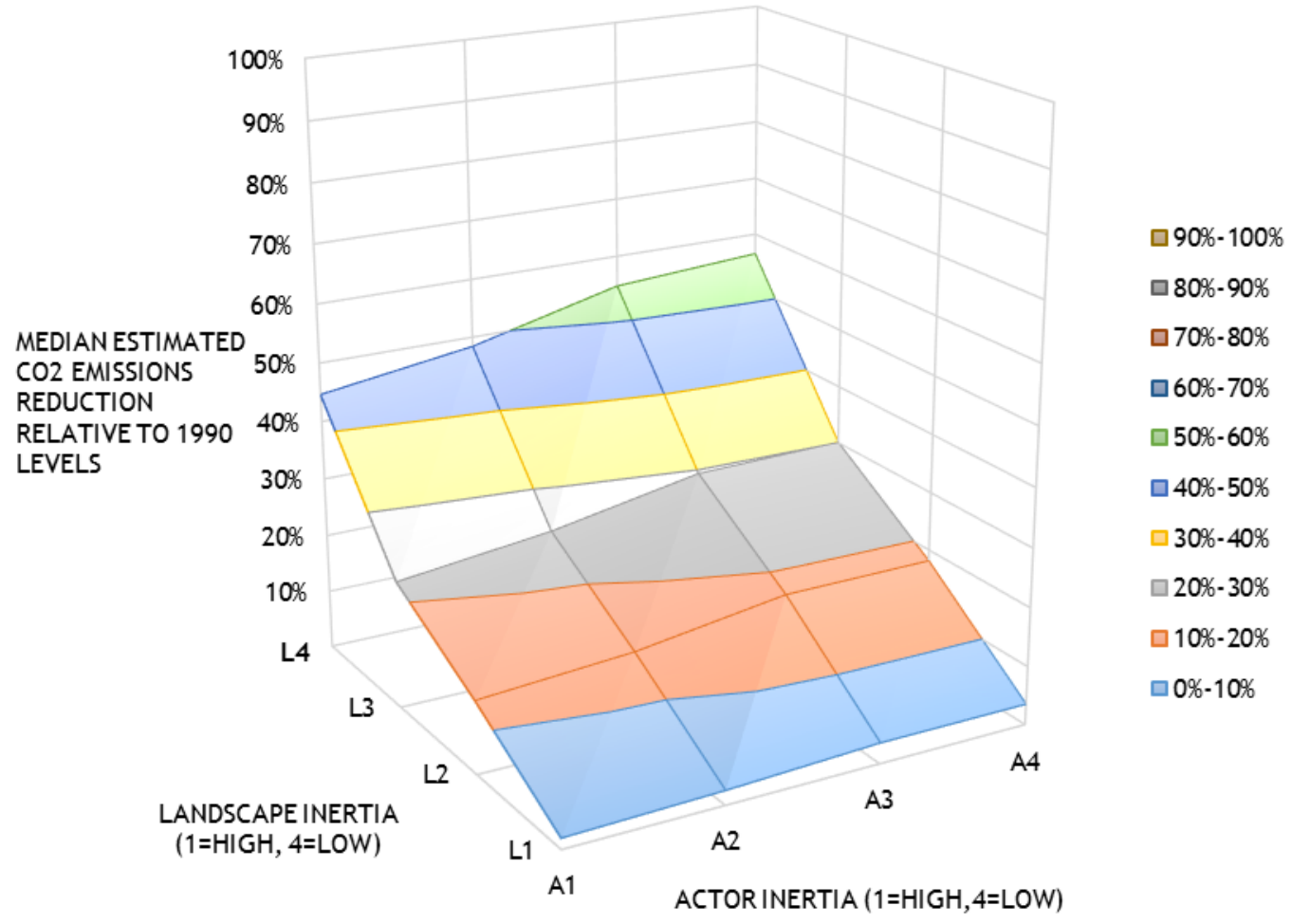




\subsubsection{Probability density for emissions reductions}

Another means of visualising the impact of actor and landscape inertia is provided in Figure 12, which takes advantage of the probabilistic nature of the BLUE model to estimate $\mathrm{CO}_{2}$ emission reductions at different confidence intervals. It can be seen that in scenarios with landscape conditions set to $\mathbf{L} \mathbf{1}, \mathbf{L} \mathbf{2}$, and $\mathbf{L} \mathbf{3}$, a part of all of the curves, regardless of the actor behaviour setting used ( $\mathbf{A}_{\mathbf{1}} \mathbf{-} \mathbf{A}_{\mathbf{4}}$ ), extend into the negative range. This means that for these scenarios, uncertainty in factors such as future fuel prices and technology costs (see Section 2.3) result in a non-negligible chance that emissions might increase.

The only scenarios that were consistently observed in simulation to deliver emissions reductions by 2050 were those with landscape conditions set to $\mathbf{L} \mathbf{4}$, which implies both strong government support for low carbon technologies (via a high carbon tax) and significant lifestyle change compared to the baseline (air travel demand stabilising per capita at 2020 levels instead of quadrupling by 2050). Even under these conditions, the observed uncertainty range is large, with emissions reductions compared to 1990 levels ranging from 35 to $71 \%$. From a policy perspective, the results show that even if the government can increase the carbon price signal to the highest level currently envisaged by $2050\left(300 \mathrm{f} / \mathrm{tCO}_{2}\right)$, then the UK's climate targets for 2050 are never met in simulation. With lower carbon prices, only modest carbon savings are observed at best, and sometimes none at all.

Another general observation is that the impact of actor behaviour appears larger when landscape conditions favour decarbonisation. It can be seen in Figure 12 that the L1 group of scenarios are very tightly clustered together, regardless of the actor inertia setting (A1 - $\left.\mathbf{A}_{\mathbf{4}}\right)$. Groups $\mathbf{L} \mathbf{2}, \mathbf{L} \mathbf{3}$, and $\mathbf{L} \mathbf{4}$ exhibit progressively greater spreads between results under actor settings at $\mathbf{A}_{\mathbf{1}}$ and at $\mathbf{A}_{\mathbf{4}}$. This is intuitive. When there is no carbon tax (L1 group), price related behaviour has little impact on the outcome visà-vis emissions. When there is a high carbon tax on the other hand (L4 group), the behavioural responses to this price signal becomes increasingly important. 
literature. Increasing government action through subsidy removal for high carbon technologies and strong, sustained support for low carbon ones, is another option. However, our analysis here suggests that this could involve going beyond the highest carbon price so far envisaged by the UK government (300 $\mathrm{f} / \mathrm{tCO}_{2}$ in 2050). Finally, there is the question of end use energy demand and lifestyle change. The baseline pathway for energy demand modelled in this paper takes the government's central view as a starting point, and already includes significant thermal efficiency improvements to buildings and a broadly stable per capita demand for electricity. Accordingly, we focused our investigation of lifestyle change around transport behaviours. Aviation was identified as a particularly challenging sector and one where stabilising demand growth was observed in simulation to have a major effect on the viability of hitting climate targets (see Figure $\mathbf{1 2}$, and compare the $L_{3}$ and $L_{4}$ scenario groups).

The introduction of both high carbon taxes and government policies aimed at changing transport behaviours face demanding hurdles to implementation. Policies that may be perceived as restricting individual freedom to travel on aircraft appear unlikely to gain traction with voters in developed countries, at least in the near-term [102]. Without a strong social mandate, it also remains an open question as to whether any democratically elected government would be able to implement high carbon taxes without simply being voted out of office [103]. How and whether social attitudes may change in future as a result of increasing exposure to climate change impacts remains to be seen. Policymakers in the UK should continue with ambitious climate mitigation efforts but it is possible that the framing of the target may need to be reconsidered. In particular, exploring the viability of a post-2050 target based around achieving a net-zero emissions position in line with the Paris Agreement could be a useful starting point.

\subsection{Implications for research}

As discussed in Section 1.0, many energy models used in policy analysis frequently focus on technological performance and draw conclusions based on the assumption that rational choice behaviour will guide economic decisions. We have argued that this relatively narrow focus overlooks important insights that can be obtained from integrating a wider range of social and behavioural elements into energy modelling. The results presented here illustrate that energy transitions to sustainability face an uphill struggle when actor responses and landscape factors are not well aligned and complementary to one another. We would argue that these are factors that cannot simply be ignored or assumed to have a minimal effect in quantitative energy policy analysis, given the obvious impacts that landscape and actor inertia have on achieving climate targets. While landscape conditions appear to be the dominant deciding factor, our initial work shows that even under strong price signals the micro-economic behaviour of individual actors can exert a strong drag effect (see Section 4.2).

Models based around economic optimisation remain highly useful in that they can demonstrate how to achieve ambitious pathways for emissions reductions in a "first best" policy world with few barriers. This can be a pragmatic approach when 
technological and resource uncertainties remain large and unexplored, as is the case for many countries which are in the process of developing their decarbonisation pathways [104]. However, in some countries, such as the UK, the cost optimal pathways for achieving energy system change are already well explored in multiple analyses [67-70]. The key question for UK policymakers is therefore now one of implementation. Here, rational optimisation models face limitations when used to assess the viability of achieving targets in "second best" policy worlds [7] that account for social and political barriers. We would argue that cost minimised pathways from optimisation analyses should therefore be thought of as techno-economic maxima, with approaches that incorporate the behaviours of multiple actors used to explore the socio-technical feasibility of climate targets.

The analysis in this paper demonstrates that climate mitigation strategies which rely only on technological change potentially offer a narrow and uncertain solution space when considering a 2050 target date for deep decarbonisation. Looking beyond direct technology substitution and market design to explore changes to behaviour, lifestyles, institutions, and culture might play an important role in expanding the solution space. Articulating the energy demand implications of new means of societal organisation, decision making, and resource allocation in a climate constrained world is a key area for future interdisciplinary research, as is understanding how social and technological change can be accelerated though institutional reform, nullifying the influence of vested interests, and shifting societal preferences towards sustainability through information provision and education.

There is much enthusiasm in parts of the transitions community regarding the future prospects for modelling societal transitions [105]. However, some have opined that full integration of quantitative modelling and qualitative transitions approaches may be unlikely given the foundational differences in scientific philosophy between the disciplines [106]. Li et al. discuss at length the challenges faced by those seeking to model socio-technical change and explicitly acknowledge that "some elements of socio-technical transitions may always lie outside of the capability of any formal analysis" [47]. There undoubtedly remains significant scope for models to improve their level of societal realism, advance their representation of actor behaviour, and capture the co-evolving nature of governance, technology and society. But an interdisciplinary approach to forward-looking evaluation strategies that recognises the value of articulating different forms of knowledge and includes a role for both formal modelling and qualitative interpretation, is both desirable and necessary. The transitions community is currently forging ahead with new approaches for structuring dialogue between practitioners from different analytical backgrounds, including the concept of "bridging" between disciplines advanced by McDowall, Turnheim, Li and Geels [106-109].

\subsection{Limitations and future work}

To the knowledge of the authors, the work explored in this paper represents the first time that a socio-technical energy transition (STET) model has been used to assess the viability of legislated climate targets across a whole multi-sectoral national 
energy system. This is an important step towards operationalising the insights from socio-technical transitions theory into the type of quantitative energy policy analysis activity that is typically practiced in government. It is a challenge for all research into behaviour to calibrate models with empirical data, which is often sparse and difficult to implement as model variables. For detailed discussion of the challenges associated with translation of observed micro-economic effects into a model of user choice behaviour the reader should refer to work by Driscoll and Holden [110]. However, difficulties of this nature do not justify ignoring or excluding actor behavioural parameters from modelling, and we have taken a pragmatic view in this work.

To account for the unknown nature of many micro-economic parameters (such as market heterogeneity, price elasticities etc.), our analysis explores a range of plausible values between maxima and minima informed by the literature on behavioural economics. Additionally, the model structure enables future calibration with empirical data (for example, stated or revealed preference data from surveys) to occur in future, as demonstrated in other models with detailed micro-economic parameters, such as CIMS, which also employs statistical simulation of unknown behavioural parameters [111]. For a robust discussion of the challenges in validating socio-technical energy transition (STET) models, the reader should refer to work by Li et al. [47].

There are a number of promising avenues for future work in this area. The analysis presented here separated micro-economic decision making behaviour from political attitudes to climate mitigation and lifestyle choices around energy service demand, both of which could also be considered "behaviour" in a more general sense, and which could be disentangled further. There is also additional scope to refine the representation of how actors and institutions interact, drawing insights from the literature on political economy and governance (e.g. [112]). For example, expanding the representation of institutional decision making to explore the effect of policy continuity and political uncertainty on energy transitions [113], perhaps using an explicit government actor. There may also be scope to implement in the model actors who actively oppose the transition. Recent transitions studies have shown that established players in the incumbent socio-technical regime, far from being passive or inert bystanders in energy transitions, may in fact attempt to aggressively defend their interests through active resistance $[114,115]$. Finally, exploring mechanisms for accelerating transitions is a vital activity, and future work may draw on the existing transitions literature on rapid decarbonisation, tipping points and breaking out of lock-in $[116,117]$. Capturing these dynamics would require the addition of a number of non-linear feedback loops to the existing BLUE model (for example, social influence effects [118]) as well as an empirical basis to enable these to be calibrated.

\subsection{Conclusions}

While there is no doubt that technology has a central role to play in transitioning the world to a climate stabilised future, there is a prevailing tendency in much of the energy modelling literature for mitigation options to be analysed more or less exclusively under "first-best" socio-political contexts. This risks downplaying the 
daunting barriers to socio-technical change posed by systemic inertia in the energy system. Here, we have explored the challenge of achieving GHG reduction targets when actor behaviour and landscape drivers are not aligned, as is often the case under "second-best" policy conditions.

We quantify these factors in a formal model as "landscape and actor inertia" and employ them for the first time in a dynamic stochastic socio-technical simulation of technology diffusion, energy and emissions in order to assess the potential for the UK energy system to transition to a low carbon future. We show that actor inertia can impose a high drag effect on climate mitigation efforts even under strong price signals from government, and also that without measures to reduce end use energy demand, the chances of achieving very deep reductions in GHG emissions by 2050 are significantly impaired.

In the case of the UK, the analysis presented in this paper shows that national climate targets for 2050 remain out of reach in simulation, even when using some of the most optimistic technology cost and performance assumptions drawn from the current literature. This is because landscape and actor inertial effects prevent the diffusion of innovative low carbon technologies occurring with sufficient speed to break the system out of lock-in before the target date. This leaves policymakers with difficult choices around the achievement of stringent climate targets and if the only viable approach is on largely speculative strategies based around negative emissions sequestration. Research that goes beyond technology and markets and aims to expand the solution space for deep decarbonisation through understanding potential contributions from changes to behaviour, lifestyles and governance is urgently needed, as is work that explores how the uptake of socio-technical innovations can be accelerated to bring about transitions on a timescale compatible with a $2{ }^{\circ} \mathrm{C}$ world.

We argue strongly that an improved representation of behaviour in energy modelling for policy is urgently required. Exploring resource and technology-based uncertainties remain important but should now be complemented with research that explores transformative energy system pathways, capturing the interactions of actors and institutions, and considering radical innovations in governance, behaviour and lifestyles. These efforts necessitate the development of a new generation of models, and interdisciplinary research that builds on past approaches to incorporate insights from both quantitative modelling studies and the field of socio-technical transitions.

\subsection{Acknowledgements}

This paper builds on research carried out under the 'Realising Transition Pathways' Project funded by the UK Engineering and Physical Sciences Research Council (EPSRC) under Grant EP/Ko05316/1. The views expressed here are those of the authors alone. The authors would like to thank the two anonymous reviewers whose useful comments and feedback helped to improve the quality of the final paper. 


\subsection{References}

[1] UNFCCC, Adoption of the Paris Agreement: Proposal by the President: Draft decision -/CP.21, United Nations Framework Convention on Climate Change (UNFCCC), 2015. http://unfccc.int/resource/docs/2015/cop21/eng/logro1.pdf.

[2] IPCC, IPCC Fifth Assessment Synthesis Report: Climate Change 2014, Intergovernmental Panel on Climate Change (IPCC), 2014.

http://www.ipcc.ch/pdf/assessmentreport/ar5/syr/SYR_AR5_LONGERREPORT.pdf.

[3] UNFCCC, Synthesis report on the aggregate effect of the intended nationally determined contributions, United Nations Framework Convention on Climate Change (UNFCCC), 2015. http://unfccc.int/resource/docs/2015/cop21/eng/07.pdf.

[4] D.G. Victor, C.F. Kennel, Climate policy: Ditch the $2{ }^{\circ} \mathrm{C}$ warming goal, Nature. 514 (2014) 30-31. doi:10.1038/514030a.

[5] T. Bruckner, I.A. Bashmakov, Y. Mulugetta, H. Chum, A. De la Vega Navarro, J. Edmonds, et al., Energy Systems, in: O. Edenhofer, R. Pichs-Madruga, Y. Sokona, E. Farahani, S. Kadner, K. Seyboth, et al. (Eds.), Clim. Chang. 2014 Mitig. Clim. Chang. Contrib. Work. Gr. III to Fifth Assess. Rep. Intergov. Panel Clim. Chang., Cambridge University Press, Cambridge, United Kingdom and New York, NY, USA, 2014: p. 139. http://report.mitigation2014.org/drafts/finaldraft-postplenary/ipcc_wg3_ar5_final-draft_postplenary_chapter7.pdf.

[6] C. Bertram, N. Johnson, G. Luderer, K. Riahi, M. Isaac, J. Eom, Carbon lock-in through capital stock inertia associated with weak near-term climate policies, Technol. Forecast. Soc. Change. 90 (2015) 62-72. doi:10.1016/j.techfore.2013.10.001.

[7] N. Strachan, W. Usher, Failure to achieve stringent carbon reduction targets in a second-best policy world, Clim. Change. 113 (2011) 121-139. doi:10.1007/s10584-011-0267-6.

[8] N. Hughes, N. Strachan, Methodological review of UK and international low carbon scenarios, Energy Policy. 38 (2010) 6056-6065. doi:10.1016/j.enpol.2010.05.061.

[9] J.-C. Hourcade, M. Jaccard, C. Bataille, F. Ghersi, Hybrid Modeling: New Answers to Old Challenges, Energy J. SI2006 (2006). doi:10.5547/ISSN01956574-EJ-VolSI2006-NoSI2-1.

[10] E.J.L. Chappin, A. Ligtvoet, Transition and transformation: A bibliometric analysis of two scientific networks researching socio-technical change, Renew. Sustain. Energy Rev. 30 (2014) 715-723. doi:10.1016/j.rser.2013.11.013.

[11] F.W. Geels, Technological Transitions and System Innovations: A Coevolutionary and Socio-Technical Analysis, Edward Elgar, Cheltenham, UK, 
2005. doi:10.4337/9781845424596.

[12] T.P. Hughes, The evolution of large technological systems, in: W. Bijker, T.P. Hughes, T. Pinch (Eds.), Soc. Constr. Technol. Syst. New Dir. Sociol. Hist. Technol., MIT Press, Cambridge, Massachusetts, USA, 1987: pp. 51-82.

[13] M. Ottens, M. Franssen, P. Kroes, I. Van De Poel, Modelling infrastructures as socio-technical systems, Int. J. Crit. Infrastructures. 2 (2006) 133. doi:10.1504/IJCIS.2006.009433.

[14] B.K. Sovacool, Rejecting renewables: The socio-technical impediments to renewable electricity in the United States, Energy Policy. 37 (2009) 4500-4513. doi:10.1016/j.enpol.2009.05.073.

[15] W.B. Arthur, Competing Technologies, Increasing Returns, and Lock-In by Historical Events, Econ. J. 99 (1989) 116. doi:10.2307/2234208.

[16] G.C. Unruh, Understanding carbon lock-in, Energy Policy. 28 (2000) 817-830. doi:10.1016/S0301-4215(00)00070-7.

[17] J. Markard, R. Raven, B. Truffer, Sustainability transitions: An emerging field of research and its prospects, Res. Policy. 41 (2012) 955-967.

doi:10.1016/j.respol.2012.02.013.

[18] F.W. Geels, The multi-level perspective on sustainability transitions: Responses to seven criticisms, Environ. Innov. Soc. Transitions. 1 (2011) 24-40. doi:10.1016/j.eist.2011.02.002.

[19] R. Fouquet, The slow search for solutions: Lessons from historical energy transitions by sector and service, Energy Policy. 38 (2010) 6586-6596. doi:10.1016/j.enpol.2010.06.029.

[20] G.C. Unruh, Escaping carbon lock-in, Energy Policy. 30 (2002) 317-325. doi:10.1016/S0301-4215(01)00098-2.

[21] W. Dolfsma, L. Leydesdorff, Lock-in and break-out from technological trajectories: Modeling and policy implications, Technol. Forecast. Soc. Change. 76 (2009) 932-941. doi:10.1016/j.techfore.2009.02.004.

[22] C. Wilson, A. Grübler, Lessons from the history of technological change for clean energy scenarios and policies, Nat. Resour. Forum. 35 (2011) 165-184. doi:10.1111/j.1477-8947.2011.01386.x.

[23] A. García-Olivares, J. Solé, End of growth and the structural instability of capitalism-From capitalism to a Symbiotic Economy, Futures. 68 (2015) 3143. doi:10.1016/j.futures.2014.09.004.

[24] M.A. Delucchi, M.Z. Jacobson, Providing all global energy with wind, water, and solar power, Part II: Reliability, system and transmission costs, and policies, Energy Policy. 39 (2011) 1170-1190. doi:10.1016/j.enpol.2010.11.045.

[25] G.J. Kramer, M. Haigh, No quick switch to low-carbon energy, Nature. 462 
(2009) 568-569. doi:10.1038/462568a.

[26] F.W. Geels, Technological transitions as evolutionary reconfiguration processes: a multi-level perspective and a case-study, Res. Policy. 31 (2002) 1257-1274. doi:10.1016/Soo48-7333(02)00062-8.

[27] H. van (Hugo) Driel, J. Schot, Radical Innovation as a Multilevel Process: Introducing Floating Grain Elevators in the Port of Rotterdam, Technol. Cult. 46 (2005) 51-76. doi:10.1353/tech.2005.0011.

[28] J. Köhler, L. Whitmarsh, B. Nykvist, M. Schilperoord, N. Bergman, A. Haxeltine, A transitions model for sustainable mobility, Ecol. Econ. 68 (2009) 2985-2995. doi:10.1016/j.ecolecon.2009.06.027.

[29] G. Papachristos, A system dynamics model of socio-technical regime transitions, Environ. Innov. Soc. Transitions. 1 (2011) 202-233. doi:10.1016/j.eist.2011.10.001.

[30] C. Wilson, H. Dowlatabadi, Models of Decision Making and Residential Energy Use, Annu. Rev. Environ. Resour. 32 (2007) 169-203. doi:10.1146/annurev.energy.32.053006.141137.

[31] H.A. Simon, A Behavioral Model of Rational Choice, Q. J. Econ. 69 (1955) 99. doi:10.2307/1884852.

[32] J.F. Shogren, L.O. Taylor, On Behavioral-Environmental Economics, Rev. Environ. Econ. Policy. 2 (2008) 26-44. doi:10.1093/reep/remo27.

[33] A.B. Jaffe, R.N. Stavins, The energy-efficiency gap What does it mean?, Energy Policy. 22 (1994) 804-810. doi:10.1016/0301-4215(94)90138-4.

[34] M. Dowson, A. Poole, D. Harrison, G. Susman, Domestic UK retrofit challenge: Barriers, incentives and current performance leading into the Green Deal, Energy Policy. 50 (2012) 294-305. doi:10.1016/j.enpol.2012.07.019.

[35] R. Galvin, Why German homeowners are reluctant to retrofit, Build. Res. Inf. 42 (2014) 398-408. doi:10.1080/09613218.2014.882738.

[36] J. Markard, B. Truffer, Technological innovation systems and the multi-level perspective: Towards an integrated framework, Res. Policy. 37 (2008) 596-615. doi:10.1016/j.respol.2008.01.004.

[37] A. Genus, A.-M. Coles, Rethinking the multi-level perspective of technological transitions, Res. Policy. 37 (2008) 1436-1445. doi:10.1016/j.respol.2008.05.006.

[38] N. Strachan, UK energy policy ambition and UK energy modelling-fit for purpose?, Energy Policy. 39 (2011) 1037-1040. doi:10.1016/j.enpol.2011.01.015.

[39] S. Pfenninger, A. Hawkes, J. Keirstead, Energy systems modeling for twentyfirst century energy challenges, Renew. Sustain. Energy Rev. 33 (2014) 74-86. doi:10.1016/j.rser.2014.02.003. 
[40] S. Jebaraj, S. Iniyan, A review of energy models, Renew. Sustain. Energy Rev. 10 (2006) 281-311. doi:10.1016/j.rser.2004.09.004.

[41] S.C. Bhattacharyya, G.R. Timilsina, A review of energy system models, Int. J. Energy Sect. Manag. 4 (2010) 494-518. doi:10.1108/17506221011092742.

[42] I. Dyner, C.J. Franco, Consumers' bounded rationality: the case of competitive energy markets, Syst. Res. Behav. Sci. 21 (2004) 373-389. doi:10.1002/sres.644.

[43] L. Clarke, K. Jiang, K. Akimoto, M. Babiker, G. Blanford, K. Fisher-Vanden, et al., Assessing Transformation Pathways, in: O. Edenhofer, R. Pichs-Madruga, Y. Sokona, E. Farahani, S. Kadner, K. Seyboth, et al. (Eds.), Clim. Chang. 2014 Mitig. Clim. Chang. Contrib. Work. Gr. III to Fifth Assess. Rep. Intergov. Panel Clim. Chang., Cambridge University Press, Cambridge, United Kingdom and New York, NY, USA, 2014: pp. 413-510. https://www.ipcc.ch/pdf/assessmentreport/ar5/wg3/ipcc_wg3_ar5_chapter6.pdf.

[44] S. Dietz, J. Michie, C. Oughton, The Political Economy of the Environment: An Interdisciplinary Approach, Routledge, 2011.

https://www.routledge.com/products/9780415437530.

[45] S.K. Nielsen, K. Karlsson, Energy scenarios: a review of methods, uses and suggestions for improvement, Int. J. Glob. Energy Issues. 27 (2007) 302. doi:10.1504/IJGEI.2007.014350.

[46] T.J. Foxon, Transition pathways for a UK low carbon electricity future, Energy Policy. 52 (2013) 10-24. doi:10.1016/j.enpol.2012.04.001.

[47] F.G.N. Li, E. Trutnevyte, N. Strachan, A review of socio-technical energy transition (STET) models, Technol. Forecast. Soc. Change. 100 (2015) 290-305. doi:10.1016/j.techfore.2015.07.017.

[48] P. Fortes, A. Alvarenga, J. Seixas, S. Rodrigues, Long-term energy scenarios: Bridging the gap between socio-economic storylines and energy modeling, Technol. Forecast. Soc. Change. 91 (2015) 161-178. doi:10.1016/j.techfore.2014.02.006.

[49] C. McGlade, P. Ekins, The geographical distribution of fossil fuels unused when limiting global warming to $2{ }^{\circ} \mathrm{C}$, Nature. 517 (2015) 187-190. doi:10.1038/nature14016.

[50] O. Edenhofer, B. Knopf, T. Barker, L. Baumstark, E. Bellevrat, B. Chateau, et al., The Economics of Low Stabilization: Model Comparison of Mitigation Strategies and Costs, Energy J. 31 (2010). doi:10.5547/ISSN0195-6574-EJ-Vol31NoSI-2.

[51] S. Natarajan, G.J. Levermore, Domestic futures-Which way to a low-carbon housing stock?, Energy Policy. 35 (2007) 5728-5736.

doi:10.1016/j.enpol.2007.05.033.

[52] J. Speirs, R. Gross, S. Deshmukh, P. Heptonstall, L. Munuera, M. Leach, et al., 
Building a roadmap for heat: 2050 scenarios and heat delivery in the UK, Imperial College ICEPT (Imperial Centre for Energy Policy and Technology) and University of Surrey Centre for Environmental Strategy, 2010.

http://www.chpa.co.uk/medialibrary/2011/04/07/egagf61d/Building_a_roadma p_for_heat_Full.pdf.

[53] J. Barton, S. Huang, D. Infield, M. Leach, D. Ogunkunle, J. Torriti, et al., The evolution of electricity demand and the role for demand side participation, in buildings and transport, Energy Policy. 52 (2013) 85-102.

doi:10.1016/j.enpol.2012.08.040.

[54] W. Leighty, J.M. Ogden, C. Yang, Modeling transitions in the California lightduty vehicles sector to achieve deep reductions in transportation greenhouse gas emissions, Energy Policy. 44 (2012) 52-67. doi:10.1016/j.enpol.2012.01.013.

[55] L. Girardin, F. Marechal, M. Dubuis, N. Calame-Darbellay, D. Favrat, EnerGis: A geographical information based system for the evaluation of integrated energy conversion systems in urban areas, Energy. 35 (2010) 830-840.

doi:10.1016/j.energy.2009.08.018.

[56] A. Weidlich, D. Veit, A critical survey of agent-based wholesale electricity market models, Energy Econ. 30 (2008) 1728-1759.

doi:10.1016/j.eneco.2008.01.003.

[57] M.G. Mueller, P. de Haan, How much do incentives affect car purchase? Agentbased microsimulation of consumer choice of new cars-Part I: Model structure, simulation of bounded rationality, and model validation, Energy Policy. 37 (2009) 1072-1082. doi:10.1016/j.enpol.2008.11.002.

[58] P. de Haan, M.G. Mueller, R.W. Scholz, How much do incentives affect car purchase? Agent-based microsimulation of consumer choice of new cars-Part II: Forecasting effects of feebates based on energy-efficiency, Energy Policy. 37 (2009) 1083-1094. doi:10.1016/j.enpol.2008.11.003.

[59] R. Kempener, J. Beck, J. Petrie, Design and Analysis of Bioenergy Networks: A Complex Adaptive Systems Approach, J. Ind. Ecol. 13 (2009) 284-305. doi:10.1111/j.1530-9290.2009.00120.x.

[6o] J. Köhler, M. Wietschel, L. Whitmarsh, D. Keles, W. Schade, Infrastructure investment for a transition to hydrogen automobiles, Technol. Forecast. Soc. Change. 77 (2010) 1237-1248. doi:10.1016/j.techfore.2010.03.010.

[61] J.H. Kwakkel, G. Yücel, An Exploratory Analysis of the Dutch Electricity System in Transition, J. Knowl. Econ. (2012). doi:10.1007/s13132-012-0128-1.

[62] M.D. Gerst, P. Wang, A. Roventini, G. Fagiolo, G. Dosi, R.B. Howarth, et al., Agent-based modeling of climate policy: An introduction to the ENGAGE multi-level model framework, Environ. Model. Softw. 44 (2013) 62-75. doi:10.1016/j.envsoft.2012.09.002.

[63] L.-G. Giraudet, C. Guivarch, P. Quirion, Exploring the potential for energy 
conservation in French households through hybrid modeling, Energy Econ. 34 (2012) 426-445. doi:10.1016/j.eneco.2011.07.010.

[64] M.D. Grubb, Failing to Choose the Best Price: Theory, Evidence, and Policy, Rev. Ind. Organ. 47 (2015) 303-340. doi:10.1007/s11151-015-9476-x.

[65] N. Rivers, M. Jaccard, Combining Top-Down and Bottom-Up Approaches to Energy-Economy Modeling Using Discrete Choice Methods, Energy J. 26 (2005). doi:10.5547/ISSNo195-6574-EJ-Vol26-No1-4.

[66] F.G.N. Li, BLUE: Behaviour Lifestyles and Uncertainty Energy model, UCL Energy Institute, London, UK, 2016. https://www.ucl.ac.uk/energymodels/models/blue.

[67] N. Strachan, R. Kannan, S. Pye, Scenarios and Sensitivities on Long-term UK Carbon Reductions using the UK MARKAL and MARKAL-Macro Energy System Models, 2008.

[68] P. Ekins, G. Anandarajah, N. Strachan, Towards a low-carbon economy: scenarios and policies for the UK, Clim. Policy. 11 (2011) 865-882. doi:10.3763/cpol.2010.0126.

[69] S. Pye, W. Usher, N. Strachan, The uncertain but critical role of demand reduction in meeting long-term energy decarbonisation targets, Energy Policy. 73 (2014) 575-586. doi:10.1016/j.enpol.2014.05.025.

[70] S. Pye, N. Sabio, N. Strachan, An integrated systematic analysis of uncertainties in UK energy transition pathways, Energy Policy. (2015). doi:10.1016/j.enpol.2014.12.031.

[71] DECC, Electricity Generation Costs (December 2013) URN 14D/005, UK Department of Energy and Climate Change (DECC), London, UK, 2013. https://www.gov.uk/government/uploads/system/uploads/attachment_data/fil e/269888/131217_Electricity_Generation_costs_report_December_2013_Final. pdf.

[72] DECC, Energy consumption in the United Kingdom: 2011 - Overall energy consumption in the UK since 1970 (Publication URN 11D/806), UK Department of Energy and Climate Change (DECC), London, UK, 2011.

[73] DECC, Quarterly Energy Prices December 2012 (URN: 12D/276d), UK Department of Energy and Climate Change (DECC), London, UK, 2012. https://www.gov.uk/government/collections/quarterly-energy-prices.

[74] DECC, Digest of United Kingdom Energy Statistics (DUKES) 2015, Department of Energy and Climate Change (DECC), London, UK, 2015. https://www.gov.uk/government/statistics/digest-of-united-kingdom-energystatistics-dukes-2015-printed-version.

[75] P. Heptonstall, A Review of Electricity Unit Cost Estimates (UKERC/WPA/TPA/2007/006), UK Energy Research Centre (UKERC), London, 
UK, 2007.

http://data.ukedc.rl.ac.uk/browse/edc/Electricity/ProductionCostEstimates/He ptonstall2007_WorkingPaper.pdf.

[76] J. Chapman, W. Goldthorpe, J. Overton, P. Dixon, P. Hare, S. Murray, The potential for reducing the costs of CCS in the UK: Interim Report of the UK Carbon Capture and Storage Cost Reduction Task Force, London, UK, 2012. https://www.gov.uk/government/uploads/system/uploads/attachment_data/fil e/198823/ccsa_ctrf_interim_report.pdf.

[77] G. Harris, P. Heptonstall, R. Gross, D. Handley, Cost estimates for nuclear power in the UK, ICEPT Working Paper (ICEPT/WP/2012/014), Imperial College Centre for Energy Policy and Technology (ICEPT), London, UK, 2012. https://workspace.imperial.ac.uk/icept/Public/Cost estimates for nuclear power in the UK.pdf.

[78] NERA, AEA, The UK Supply Curve for Renewable Heat: Study for the Department of Energy and Climate Change, Department of Energy and Climate Change (DECC), London, UK, 2009.

http://www.rhincentive.co.uk/library/regulation/ogo7Heat_Supply_Curve.pdf.

[79] DECC, Energy consumption in the United Kingdom (2015): Chapter 5 - Service sector energy consumption in the UK between 1970 and 2014 (Publication URN 15D/381), Department of Energy and Climate Change (DECC), London, UK, 2015. https://www.gov.uk/government/statistics/energy-consumption-in-theuk.

[80] Element Energy, Pathways to high penetration of electric vehicles: Final report for the Committee on Climate Change, Element Energy, Cambridge, UK, 2013. http://www.theccc.org.uk/wp-content/uploads/2013/12/CCC-EVpathways_FINAL-REPORT_17-12-13-Final.pdf.

[81] Element Energy, Influences on the Low Carbon Car Market from 2020-2030: Final Report for Low Carbon Vehicle Partnership, Element Energy, Cambridge, UK, 2011. lowcvp.org.uk/assets/reports/Influences on the Low Carbon Car Market from 2020-2030 - Final Report 010811_pdf.pdf.

[82] CCC, The Fifth Carbon Budget: The next step towards a low-carbon economy, The Committee on Climate Change (CCC), London, UK, 2015. https://documents.theccc.org.uk/wp-content/uploads/2015/11/Committee-onClimate-Change-Fifth-Carbon-Budget-Report.pdf.

[83] DECC, DECC Fossil Fuel Price Projections, July 2013 (URN 13D/170), Department of Energy and Climate Change (DECC), London, UK, 2013. https://www.gov.uk/government/uploads/system/uploads/attachment_data/fil e/212521/130718_decc-fossil-fuel-price-projections.pdf.

[84] A. Grübler, The costs of the French nuclear scale-up: A case of negative learning by doing, Energy Policy. 38 (2010) 5174-5188. doi:10.1016/j.enpol.2010.05.003. 
[85] Sweett Group, Buro Happold, ACE, Research on the costs and performance of heating and cooling technologies, 2013.

https://www.gov.uk/government/consultations/non-domestic-rhi-early-tariffreview.

[86] Frontier Economics, Element Energy, Pathways to high penetration of heat pumps, Frontier Economics and Element Energy for the Committee on Climate Change (CCC), London, UK, 2013. http://www.theccc.org.uk/wpcontent/uploads/2013/12/Frontier-Economics-Element-Energy-Pathways-tohigh-penetration-of-heat-pumps.pdf.

[87] HM Government, Climate Change Act 2008, HMSO, London, UK, 2008. http://www.legislation.gov.uk/ukpga/2008/27/pdfs/ukpga_20080027_en.pdf.

[88] DECC, Carbon Valuation in UK Policy Appraisal: A Revised Approach, London, UK, 2009.

[89] DfT, Transport Statistics Great Britain 2014, UK Department for Transport (DfT), London, UK, 2014.

https://www.gov.uk/government/uploads/system/uploads/attachment_data/fil e/389592/tsgb-2014.pdf.

[90] S. Pye, H. Daly, Modelling sustainable urban travel in a whole systems energy model, Appl. Energy. 159 (2015) 97-107. doi:10.1016/j.apenergy.2015.08.127.

[91] A. Grübler, X. Bai, T. Buettner, S. Dhakal, D.J. Fisk, T. Ichinose, et al., Urban Energy Systems, in: T.B. Johansson, N. Nakicenovic, A. Patwardhan, L. GomezEcheverri (Eds.), Glob. Energy Assess., Cambridge University Press, Cambridge, 2012: pp. 1307-1400. doi:10.1017/CBO9780511793677.024.

[92] S.K. Ribeiro, M.J. Figueroa, F. Creutzig, C. Dubeux, J. Hupe, S. Kobayashi, et al., Energy End-Use: Transport, in: T.B. Johansson, N. Nakicenovic, A. Patwardhan, L. Gomez-Echeverri (Eds.), Glob. Energy Assess., Cambridge University Press, Cambridge, 2012: pp. 575-648. doi:10.1017/CBO9780511793677.015.

[93] A.W. Schäfer, J.B. Heywood, H.D. Jacoby, I.A. Waitz, Transportation in a Climate-Constrained World, MIT Press, Cambridge, Massachusetts, USA, 2009. https://mitpress.mit.edu/books/transportation-climate-constrained-world.

[94] A.H. Hermelink, D. de Jager, Evaluating our Future: The Crucial Role of Discount Rates in European Commission Energy System Modelling, Ecofys for The European Council for an Energy Efficient Economy (eceee), 2015. http://europeanclimate.org/evaluating-our-future-the-crucial-role-of-discountrates-in-european-commission-energy-system-modelling/.

[95] HM Treasury, The Green Book: Appraisal and Evaluation in Central Government, London, UK, 2011. http://www.hmtreasury.gov.uk/d/green_book_complete.pdf.

[96] Oxera Consulting Ltd, Discount Rates for Low-Carbon and Renewable Generation Technologies: Prepared for the Committee on Climate Change, 
Oxford, UK, 2011.

[97] D. Moellendorf, Discounting the Future and the Morality in Climate Change Economics, in: Moral Chall. Danger. Clim. Chang., Cambridge University Press, New York, 2013: pp. 90-122. doi:10.1017/CBO9781139083652.005.

[98] E. Holdaway, B. Samuel, J. Greenleaf, A. Briden, A. Gardiner, The Hidden Costs and Benefits of Domestic Energy Efficiency and Carbon Saving Measures, 2009. http://www.decc.gov.uk/assets/decc/what we do/supporting consumers/saving_energy/analysis/1_20100111103046_e_@@@ecofyshiddenc ostandbenefitsdefrafinaldec2009.pdf.

[99] S. Fuss, J.G. Canadell, G.P. Peters, M. Tavoni, R.M. Andrew, P. Ciais, et al., Betting on negative emissions, Nat. Clim. Chang. 4 (2014) 850-853. doi:10.1038/nclimate2392.

[100] P. Smith, S.J. Davis, F. Creutzig, S. Fuss, J. Minx, B. Gabrielle, et al., Biophysical and economic limits to negative $\mathrm{CO}_{2}$ emissions, Nat. Clim. Chang. 6 (2015) 4250. doi:10.1038/nclimate2870.

[101] K. Anderson, Duality in climate science, Nat. Geosci. (2015). doi:10.1038/nge02559.

[102] J. Higham, S.A. Cohen, C.T. Cavaliere, A. Reis, W. Finkler, Climate change, tourist air travel and radical emissions reduction, J. Clean. Prod. 111 (2016) 336347. doi:10.1016/j.jclepro.2014.10.100.

[103] P. Ekins, An Economic Perspective on Technological Transitions Related to Energy and Climate Change, with a Case Study of the UK, Econ. Polit. 2 (2010) 247-276. doi:10.1428/32539.

[104] Deep Decarbonization Pathways Project, Pathways to deep decarbonization 2015 report, SDSN - IDDRI, 2015. http://deepdecarbonization.org/wpcontent/uploads/2015/12/DDPP_2015_REPORT.pdf.

[105] G. Holtz, F. Alkemade, F. de Haan, J. Köhler, E. Trutnevyte, T. Luthe, et al., Prospects of modelling societal transitions: Position paper of an emerging community, Environ. Innov. Soc. Transitions. (2015). doi:10.1016/j.eist.2015.05.006.

[106] F.W. Geels, F. Berkhout, D.P. van Vuuren, Bridging analytical approaches for low-carbon transitions, Nat. Clim. Chang. 6 (2016) 576-583. doi:10.1038/nclimate2980.

[107] W. McDowall, Exploring possible transition pathways for hydrogen energy: A hybrid approach using socio-technical scenarios and energy system modelling, Futures. 63 (2014) 1-14. doi:10.1016/j.futures.2014.07.004.

[108] B. Turnheim, F. Berkhout, F. Geels, A. Hof, A. McMeekin, B. Nykvist, et al., Evaluating sustainability transitions pathways: Bridging analytical approaches to address governance challenges, Glob. Environ. Chang. 35 (2015) 239-253. 
doi:10.1016/j.gloenvcha.2015.08.010.

[109] F.G.N. Li, S. Pye, N. Strachan, Regional winners and losers in future UK energy system transitions, Energy Strateg. Rev. 13-14 (2016) 11-31.

doi:10.1016/j.esr.2016.08.002.

[110] J.C. Driscoll, S. Holden, Behavioral economics and macroeconomic models, J. Macroecon. 41 (2014) 133-147. doi:10.1016/j.jmacro.2014.05.004.

[111] D. Beugin, M. Jaccard, Statistical Simulation to Estimate Uncertain Behavioral Parameters of Hybrid Energy-Economy Models, Environ. Model. Assess. 17 (2011) 77-9o. doi:10.1007/s10666-011-9276-0.

[112] M. Nilsson, L.J. Nilsson, R. Hildingsson, J. Stripple, P.O. Eikeland, The missing link: Bringing institutions and politics into energy future studies, Futures. 43 (2011) 1117-1128. doi:10.1016/j.futures.2011.07.010.

[113] S. Fuss, D.J.A. Johansson, J. Szolgayova, M. Obersteiner, Impact of climate policy uncertainty on the adoption of electricity generating technologies, Energy Policy. 37 (2009) 733-743. doi:10.1016/j.enpol.2008.10.022.

[114] F.W. Geels, Regime Resistance against Low-Carbon Transitions: Introducing Politics and Power into the Multi-Level Perspective, Theory, Cult. Soc. 31 (2014) 21-40. doi:10.1177/0263276414531627.

[115] A. Stirling, Transforming power: Social science and the politics of energy choices, Energy Res. Soc. Sci. 1 (2014) 83-95. doi:10.1016/j.erss.2014.02.001.

[116] J. Wiseman, T. Edwards, K. Luckins, Post carbon pathways: A meta-analysis of 18 large-scale post carbon economy transition strategies, Environ. Innov. Soc. Transitions. 8 (2013) 76-93. doi:10.1016/j.eist.2013.04.001.

[117] P. Zeppini, K. Frenken, R. Kupers, Thresholds models of technological transitions, Environ. Innov. Soc. Transitions. 11 (2014) 54-70. doi:10.1016/j.eist.2013.10.002.

[118] M. Granovetter, Threshold Models of Collective Behavior, Am. J. Sociol. 83 (1978) 1420-1443. doi:10.1086/226707. 